\title{
Rekontruksi Akibat Hukum atas Sikap Nabi saw. yang Meninggalkan Suatu Amalan Tertentu (Tark al-Nabi)
}

\author{
Bakhrul Huda \\ Institut Keislaman A6dullah Faqih/6aß̧̧ruโhuda@gmail.com
}

\begin{abstract}
Differences in punishing something happen among Muslim scholars. This is not only because of the way of view in terms of dalalah al-lafd -to understand the meaning contained in the word-, but the factor has not reached nass by the others or the other's way of view that's the naș is invalid, also because of the problem of tark al$n a b i$-the attitude of the Prophet pbuh. which leaves doing something-is a vast field that also greatly supports the differences between moslems. This Terma of al-tark is one of the ways we understand and act on legal differences among Muslims. The author is interested in studying this term by library so that the results of this study could be one additional reading reference in drawing the conclusions of phenomena that occur today especially since there is a conservative dakwah disturbing spread in many social media. So we will know that the Prophet's attitude of not doing in some cases not necessarily haram or even makhruh either in the realm of worship or culture if not supported with the other theorems.
\end{abstract}

Abstrak:Perbedaan pendapat dalam menghukumi sesuatu
banyak terjadi di kalangan cendekiawan dan ulama muslim.
Hal ini tidak hanya karena cara pandang dalam terma
dalālah al-lafḍ -memahami makna terkandung dalam lafad-
, namun faktor belum sampainya suatu naș pada satu
pihak lawan atau cara pandang pihak lawan akan nașs
dipandang tidak kuat, juga karena masalah tark al-nabi -
sikap Nabi saw. yang meninggalkan suatu amal- adalah
medan luas yang juga sangat mendukung perbedaan yang
ada. Terma al-tark ini adalah salah satu cara kita
memahami dan bersikap akan perbedaan-perbedaan
hukum di kalangan kaum muslim. Penulis tertarik meneliti
terma ini secara pustaka agar hasil penelitian ini dapat jadi
salah satu tambahan refensi bacaan dalam menarik
kesimpulan fenomena-fenomena yang terjadi saat ini
terutama sejak ada dakwah konservatif yang meresahkan
tersebar di banyak media sosial. Sehingga kita akan

Al-Qānūn, Vol. 20, No. 1,Juni 2017 
mengetahui bahwa sikap dari tidak melakukannya Nabi saw. pada suatu hal belum tentu haram atau bahkan makhruh baik dalam ranah ibadah atau budaya jika tidak didukung dengan dalil-dalil yang lain.

Kata Kunci:al-Tark, Sikap Nabi, Sebab, Hukum

\section{A. Pendahuluan}

Perbedaan sosial, iklim dan juga masa merupakan beberapa faktor yang membuat masyarakat di dunia ini tidak sama satu dengan lainnya. Terkadang hanya beda masa namun secara sosial dan iklim samapun menimbulkan perbedaan. Kaitannya dengan perbedaan pendapat beberapa faktornya adalah objek yang dikaji belum terang jelas, kecenderungan dan orientasi yang subjektif, taklid buta pada pendahulu, kapasitas intelektual dan juga kekuasaan. Sehingga, perbedaan yang timbul saat ini adalah sebuah keniscayaan yang perlu kedewasaan berpikir dan juga keinginan untuk terus belajar agar tidak mudah menjustifikasi lainnya tidak baik atau jelek.

Dewasa ini kalangan konservatif menyalahkan dan mempertanyakan amalan atau perbuatan yang tidak dilakukan oleh Nabi saw. baik sifatnya ibadah maupun adat sosial yang dilakukan oleh seorang muslim di berbagai pelosok dunia. Semisal acara haul seorang yang shaleh, maulid, manaqib, istighasah, tahlilan, pujian-pujian di antara adzan dan iqamah, penambahan kata sayyid sebelum menyebut nama Nabi saw.; Muhammad dan lain sebagainya. Dakwah kaum konservatif ini bahkan sudah dapat dikatakan "meresahkan" sebab budaya haul dan seterusnya tadi sudah lekat identik di beberapa daerah khususnya di Indonesia sejak dulu. Keresahan ini dirasakan sebab metode dakwah kawan yang konservatif ini cenderung menyalahkan dan memicu konflik sosial.

Dalam tulisan ini penulis akan mencoba untuk mengungkapkan dan menganalisis sikap-sikap Nabi saw. yang meninggalkan suatu amal perbuatan baik dalam 
kategori ibadah atau lainnya yang belum ada hadis atau athar yang melarang dan menghukuminya haram atau makruh yang kita maknai sebagai tark al-nabí. Di mana saat ini banyak dari kalangan ulama tipikal konservatif dan kakuh menjadikan sikap Nabi saw. ini sebagai bukti -dengan menjadikannya sebagai bagian dari sunnah beliau- yang mengharamkan atau memakruhkan suatu amal perbuatan tersebut.

Padahal dalam penentuan haram atau makruh harus ada indikasi dalil yang mengarah pada kedua hal tersebut. Dalam hal ini para ahli Usul Fikih memberikan ciri dalil pelarangan yaitu; pertama, adanya kalimat larangan (alnahy) seperti dalam surat al-Isrä' ayat 32 terkait larangan mendekati perzinaan, surat al-Baqarah ayat 188 terkait larangan makan harta secara batil, dan hadis Nabi saw. terkait larangan untuk tidak hasut, tidak bertindak najsh (mengajukan tawaran lebih tinggi untuk mengelabuhi orang lain agar membeli dengan harga tinggi), dan tidak saling benci $^{1}$. Kedua, adanya kalimat haram, seperti larangan makan bangkai, darah dan daging babi dalam surat alMa'idah ayat 3. Ketiga, adanya celaan pada suatu amalan dan mengabarkannya akan siksaan bagi pelaku amal, seperti larangan menipu ${ }^{2}$.

Pendapat yang mengatakan bahwa al-tark bagian dari sunnah tidaklah tepat. Ulama-ulama klasik mayoritas sudah sependapat terkait definisi sunnah, seperti yang terdapat dalam literatur kitab-kitab Usul Fikih bahwa definisi dari sunnah menurut para ahli Usul Fikih adalah aqwal al-nabī wa af'aluhu wa taqäriruhu ${ }^{3}$ (segala perkataan,

1 Muslim Ibn al-Hajjāj al-Qushayrỉ al-Nisābūrỉ, Șahị Muslim Vol. 4, (Kairo: Dār Ihỵā' al-Kutub al-'Arabiyah, tt.), h. 1984.

IIbid., Vol. 1, h. 126.

3 Abū al-Hasan Sayyid al-Dīn 'Ali Ibn Abū Ali Ibn Muhammad Ibn Sālim al-Tha'labī Al-Āmadi, al-Iḥkām fi Ușul al-Ahkām Vol. 1Taḥqĩ Abd al-Razzāq 'Afifi (Bairut: Maktabah al-Islāmi, tt.), h. 169. Lihat juga Abū Ishāq Ibrāhim Ibn Mūsā Ibn Muḥammad al-Shațibì, al-Muwafaqāt Vol. 4(Kairo: Dār Ibn al-Qaym, 2003), h. 419. 
tindakan dan ketetapan Nabi saw.) dengan yang dimaksut perkataan di sini adalah segala ucapan Nabi saw. yang berkaitan dengan hukum-hukum syariat semisal :

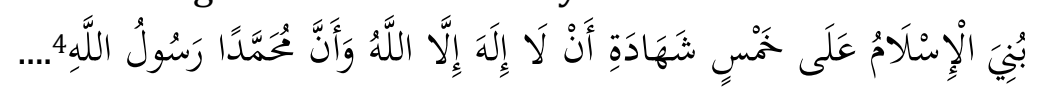

Dan yang dimaksut dengan tindakan Nabi saw. adalah segala perbuatan beliau terkait Ibadah dan lainnya seperti perilaku shalat beliau, haji, puasa dst. Sedang ketetapan Nabi saw. adalah segala pengesahan beliau terhadap apa yang beliau temukan dan ketahui dari perilaku-perilaku yang dilakukan oleh para sahabatnya tanpa ada pengingkaran dan teguran dari beliau. Hal itu dihukumi sebagai ketetapan beliau. Definisi hadis dari ahli Usul Fikih ini tidak mengkatagorikan tark (sikap meninggalkannya Nabi saw. pada suatu amalan) bagian dari definisi hadis. Namun, para ulama tektualis dan konservatif menjadikan tark al-nabi bagian dari sunnah beliau atau paling tidak ia menjadi referensi terdepan pengambilan hukum setelah sunnah qauliyah, filiyah dan taqririyah.

Sebelum kita menganalisis turuk al-nabawi ${ }^{5}$ (segala amal perbuatan yang tidak dilakukan oleh Nabi saw.),

${ }^{4}$ Muḥammad Ismā'il al-Bukhārī, Șaḥị̣ al-Bukhārí Vol. 1(Kairo: Dār Ibn Kathïr, 1993), h. 13.

5 Sighah (redaksi kata) meninggalkannya Nabi saw. pada suatu amalan dalam sunnah nabawiyah dapat dijumpai dengan kata;

1) Tark (meninggalkan), lihat Abū 'Abd Allāh Muhammad Ibn 'Abd Allāh al-Ḥākim, al-Mustadrak 'alā al-Sahịhayn Vol. 1(Kairo: Dār alMa'rifah, 1998), h. 625:

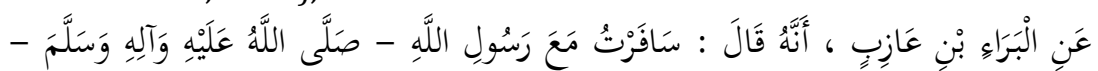

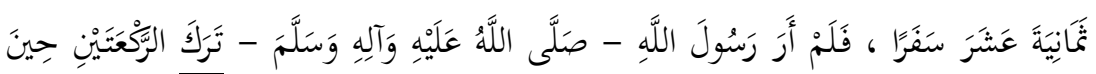
تَزِيغُ الشَّمْنُ

2) Lam yaf'aluhu (beliau tidak melakukannya), Ahmad Ibn 'Ali Ibn Hajar al-Asqalānī, Fath al-Bārí Sharh Șahịh al-Bukhārí Kitab Faḍảil al-Qur'ān(Kairo : Dar al-Rayyān li al-Turāth, 1986), h. 628: 
penulis akan memaparkan definisi tark (plural: turuk) secara etimologinya. Dari berbagai literatur, ia dapat mempunyai makna ${ }^{6}$ rafd (menolak) ${ }^{7}$, takhliyah wa ibqa (membiarkan) ${ }^{8}$, nisyān (lupa) ${ }^{9}$, 'afwu $^{-}$(memaafkan) ${ }^{10}$ dan hijrah ('adam al-ibqa'; pisah, tidak menetap) ${ }^{11}$.

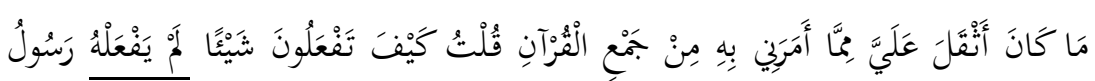

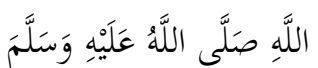

3) Kāna lā (beliau tidak pernah), lihat Muslim Ibn al-Hajjāj, al-Qushayri al-Nisābūrī, Sahịh Muslim Vol. 1, h. 613:

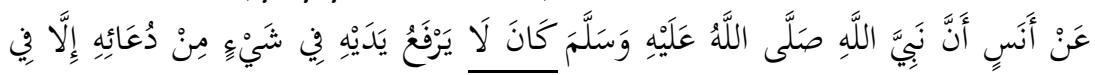
الإستنِتْنَاِي

4) yada'u (membiarkan), lihat Muhammad Ismāíl al-Bukhārỉ, Șaḥih alBukhäri Vol. 1, h. 380:

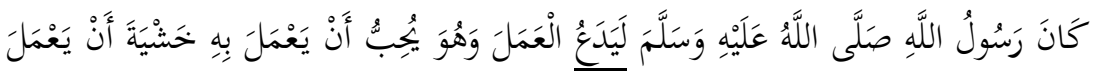

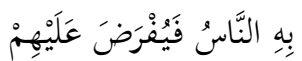

5) mā ra'aytu (saya -perawi- tidak melihat), lihat: Ibid.,Vol. 5,h. 2262:

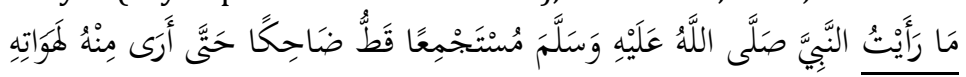

6) lam yakum (beliau belum pernah), lihat: Ibid., Vol. 1, h. 387:

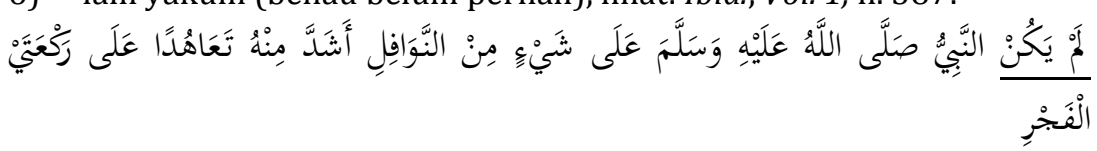

7) yaf'aluhu (beliau berbuat demikian), lihat: Ibid.,h. 167:

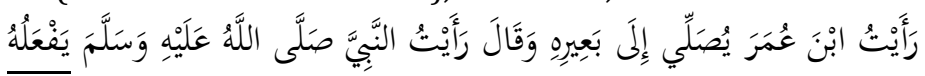

8) lā taf'al (jangan kamu lakukan), lihat: Ibid.,Vol. 2, h. 698 :

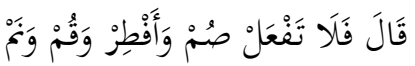

9) Lam yasunna (tidak disunnahkan), lihat: Ibid.Vol. 6, h.2489:

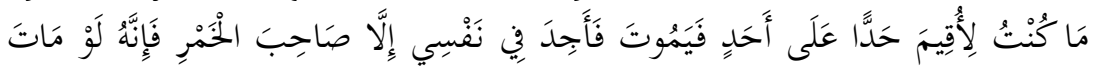

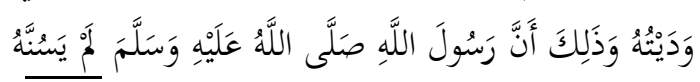

${ }^{6}$ Aḥmad Kāfi, Dalil al-Tark bayna al-Muḥaddithín wa al-Ușuliyin (Bairut: Dār al-Kutub al-'Ilmiyah, 2008), h. 25.

${ }^{7}$ Seperti dalam ayat QS. Al-Kahfi (0: 99

${ }^{8}$ Seperti dalam ayat QS. Al-Șāfāt: 78 
Turuk al-nabawiyang dimaksut di sini mempunyai definisi epistemologi sebagai berikut; menurt Imam alḤaramayn al-Juwaynī; "hakikat al-tark adalah sikap kontradiktif pada perbuatan yang ditinggal, ini bagian dari penetapan, dan tidak terjadi untuk penafian, yang demikian ini juga tidak untuk mensifati seseorang tersebut mampu untuk melakukan atau meninggalkan suatu perbuatan tersebut”. Dan Abu Hasan al-Ash'arī menerangkan bahwa "sikap meninggalkannya Nabi saw. pada sesuatu itu menunjukkan bahwa beliau sedang melakukan perbuatan sebaliknya"12. Quṭb Muștafā Sānū mendefinisikan al-tark sebagai "pengabaian dari mengerjakan suatu perkara yang dapat dilakukannya baik sengaja ataupun tidak"13. Sedang Mawlānā al-Ghumarīi14 mendefinisikan al-tark adalah "sikap meninggalkannya Nabi saw. pada sesuatu untuk tidak beliau

9 Ibn Hajar pernah berkata bahwa "lupa mengarah pada untuk meninggalkan, baik sebab kecerobohan ataupun tidak", hal ini dapat dipahami dalam ayat QS. Al-Hashr: 99 dan QS. al-Tawbah: 67.Lihat Aḥmad Kāfi, Dalil al-Tark, h. 27.

$10 \mathrm{Abū}$ 'Abd Allāh Muhammad Ibn Yazìd al-Qazwīnī, Sunan Ibn Majah(Kairo: Dār Ihyā' al-Kutub al-'Arabiyah, tt.), h. 1117:

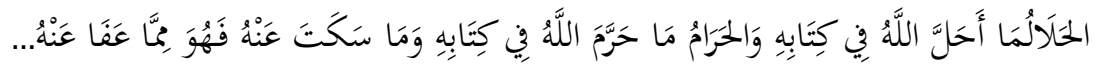
"sesuatu yang halal adalah apa yang Allah swt. halalkan dalam kitabnya (al-Qur'an), sesuatu yang haram adalah apa yang Allah swt. haramkan dalam kitabNya, dan sesuatu yang Allah swt. diamkan maka itu bentuk ampunanNya...".

11 Hal ini dipahami dari perkataan Șạib al-Fath: "bab al-hijrah bikasr al-ha' wa sukūn al-jīm ay tark al-shakhș mukalamah al-ukhrah idha talāiya-.." (bab hijrah, dengan kasrahnya huruf ha' dan sukunnya jim, yaitu putusannya seseorang untuk tidak berbincang dengan lainnya ketika bertemu...). Lihat Ahmad Kāfi, Dalil al-Tark, h. 29.

${ }^{12}$ Ibid., h. 30.

13 Quțb Muștafā Sānū, Mu'jam Muștalahạat Ușul al-Fiqh (Damaskus: Dār al-Fikr, 2000), h. 132.

14 Penulis mendapatkan sanad keilmuan yang sambung dengan Mawlānā Shekh Abū al-Faḍl 'Abd Allāh Muhammad al-Ghumārī melalui murid beliau di Mesir Mawlānā Shekh Yusrī Rushdi Jabr al-Hasani, Ulama al-Azhar yang juga dokter spesialis bedah dan Mursyid Thariqah Shiddiqiyah Syadziliyah. 
lakukan atau segala hal yang ditinggalkan para pendahulu kita yang shaleh tanpa adanya hadis dan athar yang melarang perkara -yang ditinggalkan- tersebut, yang berujung keharamannya atau kemakruhannya" 15 .

Dari sekian definisi ini, dapat kita sederhanakan bahwa al-tark adalah segala apa saja yang ditinggal oleh Allah swt (untuk tidak disebut) dalam al-Qur'an atau juga segala sesuatu yang ditinggal oleh Nabi saw. baik dengan sengaja atau tidak, lupa atau tidak dengan adanya iqtida (konsekwensi) atau tidak dalam meninggalkan perkara tersebut ${ }^{16}$. Nabi saw terkadang sengaja meninggalkan tidak melakukan suatu amalan ibadah padahal beliau sebenarnya gemar melakukan amalan tersebut sebab kwatir ia dipandang wajib. Seperti yang diungkapkan oleh sayyidah Aisyah ra.:

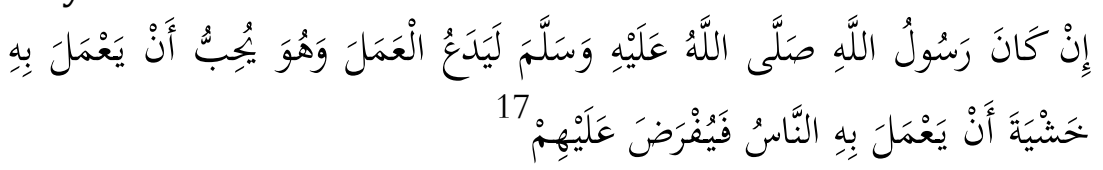

\section{B. Sikap meninggalkannya Nabi saw. pada suatu perkara dan sebabnya}

Nabi Muhammad saw. adalah manusia utusan Allah swt., sisi kemanusian beliau tidak dapat dipisahkan dalam kehidupannya ketika menyampaikan risalah. Dalam perkara menyikapi untuk tidak melakukan atau meninggalkan suatu amalan, sisi manusiawi ikut berperan. Maka, dalam hal ini penulis akan membedakan menjadi dua terkait sikap beliau

15 Abū al-Faḍl 'Abd Allāh Ibn Muhamammad Ibn al-Ṣiddiq al-Ghumārī, Husn al-Tafahhum wa al-Dark li Mas'alah al-Tark (Kairo: Maktabah alQāhirah, 2002), h. 9.

${ }^{16}$ Aḥmad Kāfi, Dalil al-Tark, h. 33-35.

17 Muhammad Ismāâl al-Bukhārī, Saḥị al-Bukhārī Vol. 1, h. 380.

"Jika Rasulullah saw. berkenan untuk meninggalkan suatu amal yang padahal beliau gemar melakukannya itu sebab beliau kwatir orang-orang mengamalkannya juga dan menjadikannya wajib". 
ini ${ }^{18}$, yaitu sikap beliau yang meninggalkan sesuatu yang masuk kategori ibadah dan sosial adat. Pertama, dalam masalah ibadah. Dari berbagai literatur yang sudah dikodifikasikan oleh para ulama hadis dapat kita jumpai kejadian yang sifatnya ibadah namun beliau tinggalkan, baik dengan sengaja maupun tidak. Berikut beberapa kejadian di mana beliau meninggalkan untuk tidak melakukan amal ibadah tersebut dan juga alasannya:

1. Nabi saw. meninggalkan shalat terawih di bulan Ramadan:

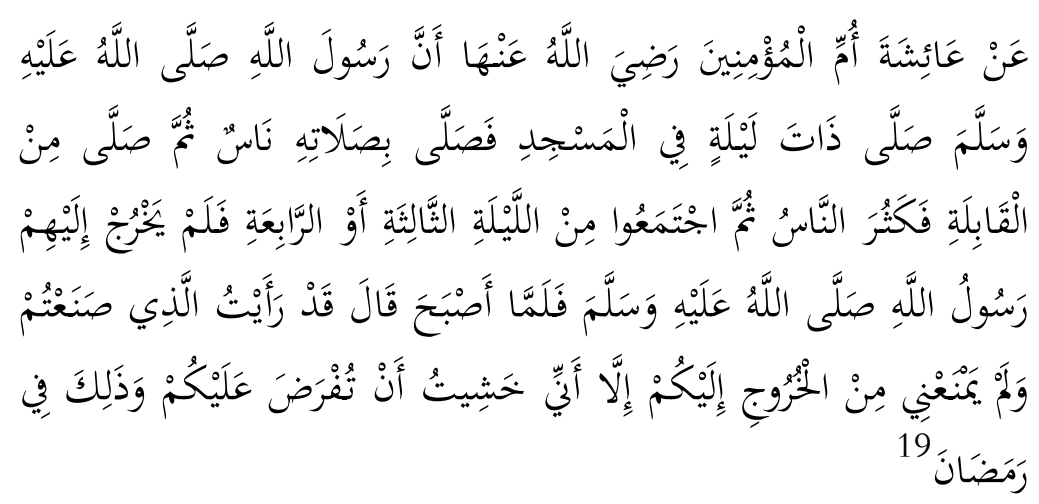

18 Mawlana al-Ghumāri mengutarakan ada enam hal yang menyebabkan Nabi saw. bersikap untuk meninggalkan suatu amal; 1) Menghormati hak yang lain semisal tidak makannya -beliau saw.bawang sebab Malaikat kurang suka dengan bau mulut orang yang memakannya. 2) Kwatir diwajibkan, seperti beliau tidak melaksanakan shalat malam di Masjid saat Ramadhan. 3). Tidak ada hal yang membuatnya terlarang atau berbahaya, seperti ketika beliau tidak menghukum mati perempuan yang ingin membunuh beliau dengan meracuni kambing yang akan dihidangkan ke beliau. 4) Sifat manusiawi beliau saw yang terkadang lupa seperti saat beliau shalat. 5) Nabi saw. tidak berpikir untuk melakukannya, seperti pembuatan mimbar untuk beliau. 6) Nabi saw. meninggalkan suatu amal sebab sudah mafhūm (dapat dipahami) dari dalil-dalil umum lainnya bahwa hal tersebut adalah sebuah kesunnahan, seperti beliau banyak meninggalkan shalat dhuha. Lihat Abū al-Faḍl 'Abd Allāh Ibn Muhammad Ibn al-Ṣiddiq alGhumāri, Husn al-Tafahhum, h. 10-11.

${ }^{19}$ Muhạammad Ismāril al-Bukhārī, Saḥiḥ al-Bukhārī Vol. 1, h. 381. 
Hadis ini menunjukkan bahwa ketiadaan Nabi saw. untuk tidak keluar rumah berjamaah dengan para sahabat sebab beliau kwatir bahwa shalat (terawih) tersebut dimaknai wajib oleh umatnya kelak. Jadi sikap tark al-nabi tidak bermakna shalat itu terlarang untuk dijalankan lagi namun agar dipahami bahwa shalat tersebut hanya merupakan amalan sunnah yang tidak wajib dan boleh tidak dilaksanakan.

2. Nabi saw. meninggalkan suatu rukun dalam shalat.

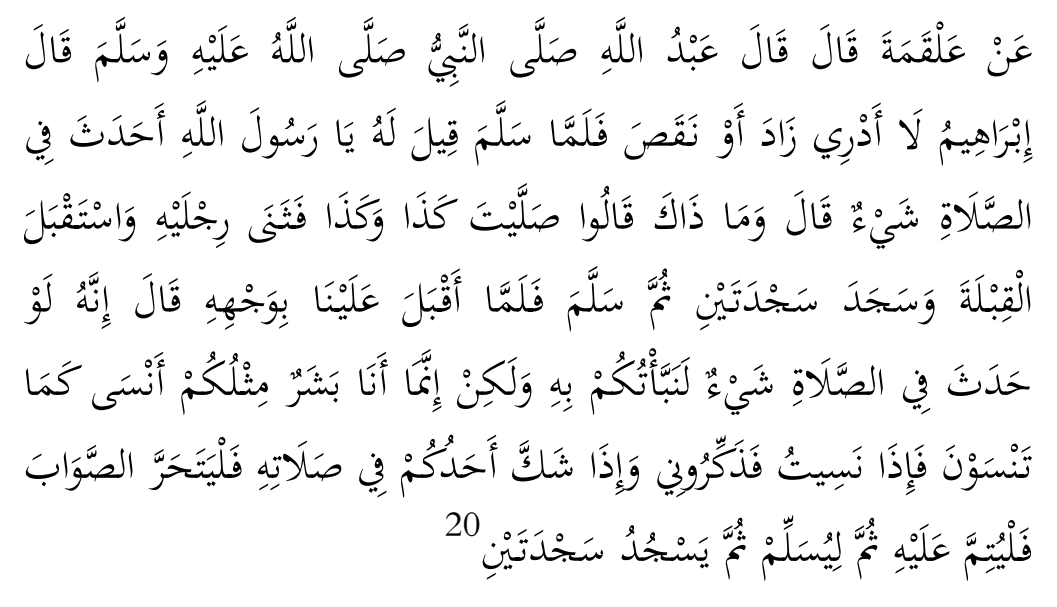

Dari sayyidah Aisyah ra. ibunya para orang mukmin, (berkata) suatu ketika sesungguhnya Rasulullah saw. melaksanakan shalat di masjid, maka orang-orang ikut shalat dengan beliau, lalu satu kelompok kafilah juga shalat sehingga jumlah orang-orang menjadi banyak, kemudian di malam ketiga atau keempat Rasulullah saw, tidak keluar rumah (untuk melaksanakan shalat bersama mereka). Dan ketika pagi hari beliau berkata: "aku sudah melihat apa yang kalian perbuat semalam dan tidak ada hal yang menghalangiku untuk keluar shalat bersama kalian, hanya saya kwatir bahwa hal itu menjadi wajib". Kejadian ini ada di bulan Ramadhan.

20 Muḥammad Ismāīil al-Bukhārỉ, Șaḥịh al-Bukhārī Vol. 1, h. 157.

Dari 'Alqamah ra. berkata, berkatalah Abdullah ra.; "Nabi saw shalat, Ibrahim ra. berkata; "saya tidak tahu pasti beliau lebih atau kurang rakaatnya", maka ketika beliau sudah salam, ditanyakanlah hal tersebut pada beliau; "wahai Rasulullah saw, apa sesuatu terjadi (pada anda) ketika shalat?". Beliau saw. menjawab; "apa itu?". Orang-orang (yang makmum) menjawab; "anda shalat semacam ini dan ini", maka beliau 
Hadis terkait lupanya Nabi saw. dalam shalat banyak para râwi hadis meriwayatkannya. Ini dapat dipahami bahwa beliau terkadang meninggalkan sesuatu itu atas dasar lupa, yang mana sebenarnya beliau tidak berkeinginan untuk meninggalkannya, hanya sebab sifat manusiawi beliau yang terkadang lupa menyebabkan beliau meninggalkan suatu rukun dalam shalat yang akhirnya ketika diingatkan oleh sahabat, beliau melakukan sujud sahwi atas apa yang telah beliau lupakan dalam shalat.

3. Nabi saw. tidak melakukan adzan dan iqamah sepanjang umur beliau.

Dalam berbagai literatur sirah nabawitidak disebutkan dan diceritakan bahwa beliau pernah melakukan adzan sekalipun, padahal adzan adalah fardu kifayah $^{21}$. Bagaimana beliau sendiri sebagai Nabi saw.

melipat kedua kaki beliau dengan menghadap kiblat kemudian beliau sujud dua kali lalu salam. Dan sesaat kemudian beliau balik menghadap ke kami dan berkata; "jika ada suatu hal terjadi dalam shalat maka tentu saya akan memberitahunya pada kalian, namun saya seperti kalian, seorang manusia yang kadang lupa, maka jika saya lupa, ingatkanlah, jika di antara kalian ragu dalam shalat maka tujukan (yakinkan) pada yang betul lalu sempurnakan shalat kalian hingga salam lalu sujudlah dua kali."

${ }^{21}$ Hukum fardu kifayah ini dapat dipahami dari hadis Nabi saw. yang menyuruh salah satu di antara sahabat untuk adzan:

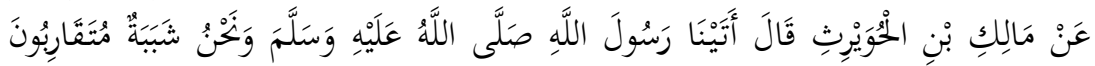

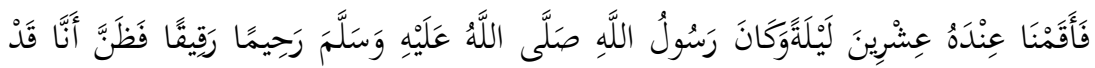

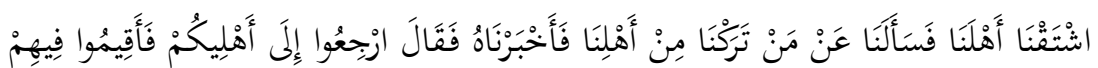

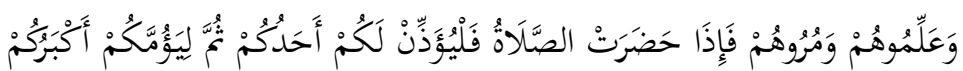

Dari Malik Ibn al-Huwayrith ia berkata, kita mendatangi Rasulullah saw. sedangkan kita (saat itu) adalah para pemuda dengan usia yang hampir sama, kita menetap di dekat Rasulullah saw. kurang lebih 20 harian. Dan beliau saw adalah orang yang penuh kasih sayang dan bersahabat dan beliau mengira bahwa kami rindu pada keluarga kami maka beliau saw bertanya pada kami tentang keluarga yang kami tinggal, maka kami 
tidak melakukan suatu hal yang sifatnya fardu, walau hanya sekali sepanjang hidup?. Tidak hanya kefarduannya, posisi beliau bagi umat adalah panutan utama, jadi dalam masalah adzan dan iqamah kita seakan tidak ada contoh dari Nabi saw. Terlebih adzan juga mempunyai keutamaan, di antaranya adalah; bahwa seorang muadzin kelak akan disaksikan bahwa ia telah melakukan amalan baik dengan bersyahadat dan mengingatkan orang untuk shalat ${ }^{22}$, orang yang adzan kelak akan masuk surga ${ }^{23}$, dan dosa muadzin diampuni sepanjang suara adzannya ${ }^{24}$.

mengabari beliau (siapa saja keluarga yang kami tinggal), maka beliau berkata; "pulanglah pada keluarga kalian, laksanakanlah di antara keluarga kalian, ajari mereka, ajaklah mereka, dan jika telah dating waktu shalat maka tunaikan adzan salah satu di antara kalian dan jadilah imam orang tertua di antara kalian."

Lihat Muslim Ibn al-Hajjāj, Sahị Muslim Vol. 1,h. 466-477. Lihat juga Muḥammad Ismāíli al-Bukhārỉ, Șahịh al-Bukhārí Vol. 1,h. 243-244.

22 Mālik Ibn Anas, Muwațta' Malik Kitảb al-Salah Vol. 1(Ttp.: Dār Ihyyā' al-'Ulūm al-'Arabiyah, 1994), h. 67-68. Lihat juga Muhammad Ismā'il al-Bukhārī, Șahị al-Bukhārí Vol. 1, h. 222:

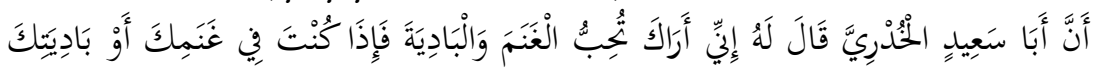

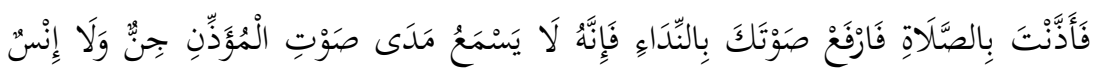

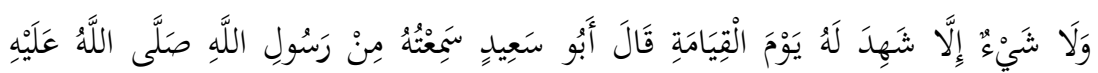

Bahwa Abū Sa'id al-Khudrī ra. berkata kepadanya (ayah al-Māzinī, perawi hadis ini); "Aku melihatmu menyukai domba dan kehidupan pedalaman, jika kamu sedang bersama dombamu atau berada di daerahmu, lalu kamu beradzan untuk shalat maka keraskanlah suaramu dalam mengajak, sebab gema suara orang yang adzan tidak didengar oleh jin atau manusia atau sesuatu pun kecuali ia memberi kesaksian untuknya pada Hari Kiamat, saya mendegar ini dari Rasulullah saw."

${ }^{23}$ Lihat Abū 'Abd Allāh Muḥammad Ibn 'Abd Allāh al-Hākim, alMustadrak 'alāal-Ṣaḥiḥayn Vol. 1, h. 446: 
Para ulama memberikan beberapa alasan terkait ketidakpernahan Nabi saw. melakukan adzan selama beliau hidup. Di antaranya ${ }^{25}$ adalah; 1). Bahwa adzan merupakan sebuah ajakan shalat. Seandainya Nabi saw. melakukan adzan maka wajib bagi yang mendengar seruan adzan beliau untuk shalat saat itu, jika tidak maka orang tersebut dapat dipastikan telah bermaksiat dengan tidak memenuhi ajakan beliau untuk shalat saat itu $^{26}$, sedangkan shalat dapat dipenuhi di awal, tengah atau bahkan akhir waktunya. 2). Eksistensi beliau adalah

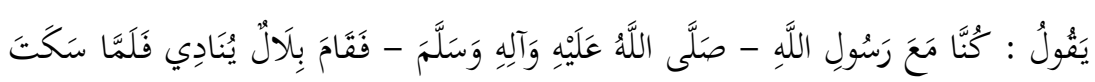

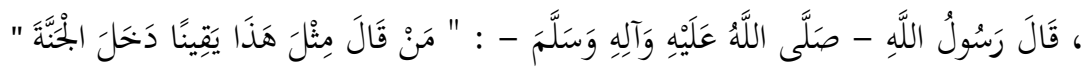

"Kami berada bersama Rasulullah saw. lalu Bilal berdirimengumandangkan adzan, ketika selesai Rasulullah saw. bersabda; "Barangsiapa mengucapkan seperti ini (adzan) dengan yakin niscaya dia masuk surga"

${ }^{24}$ Lihat Ahmad Ibn Shu'ayb Ibn 'Ali al-Nasā'i, Sunan al-Nasảît(Ttp.: Maktab al-Maṭu'āt al-Islāmiyah, 1994), h. 13-14:

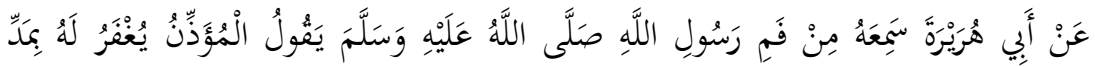

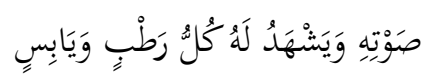

Dari Abu Hurairah bahwa dia pernah mendengar Rasulullah saw. bersabda; " seoarang muadzin diampuni dosanya sepanjang suaranya, dan segala yang basah dan yang kering bersaksi untuknya”.

25 'A Marratan Wahidan fi Hayātihi?" dalam http://islam.ahram.org.eg/NewsQ/38065.aspx,diakses pada 24/2/2018.

${ }^{26}$ Lihat Muḥammad Ismāîl al-Bukhārì, Șaḥị̣ al-Bukhārí Vol. 6, h. 2656:

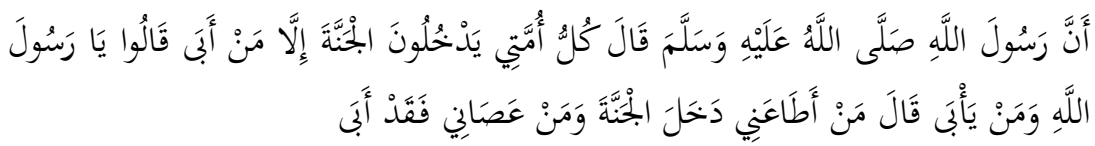

Sesungguhnya Rasulullah saw bersabda; "setiap umatku akan masuk surga kecuali yang menolak", mereka (para sahabat) bertanya; "siapa itu yang menolak?" beliau saw menjawab; "barang siapa mentaatiku maka ia masuk surga, dan barang siapa tidak taat maka ia telah menolak".

Lihat juga Muslim Ibn al-Hajjāj, Saḥiḥ Muslim Vol. 3, h. 1467. 
da'iyan ila- Allah (mengajak umat kepada Allah swt.), sedang dalam adzan ada lafal syahadat tentang dirinya yang menjadi utusan Allah swt., teruskan lafal ajakan shalat. Ini seakan-akan mengajak umat kepada beliau bukan kepada Allah swt. Atau orang-orang bisa jadi akan punya persepsi seakan-akan ada orang lain yang namanya Muhammad yang menjadi utusan Allah jika beliau sampai melafalkan ashhad anna Muhammad rasul Allah (saya bersaksi bahwa Muhammad utusan Allah). 3) Bahwa adzan datang dari mimpi seorang sahabat ${ }^{27}$ lalu beliau menetapkannya, maka perkara tersebut kembali pada sahabat agar dilaksanakan sedang beliau hanya cukup menetapkannya dan beliau disibukkan dengan perkara dakwah yang lain yang tentunya sangat

27 Muhammad Ibn “'̄sā Ibn Sūrah al-Tirmidhī, Sunan al-Tirmidhi Vol. 1(Bairut: Dār al-Kutub al-"ilmiyah, t.th.), h. 360. Lihat Ahmad Ibn 'Ali Ibn Ḥajar al-Asqalānī, Fath al-Bärī Sharh Șaḥiḥ al-Bukhärí, h. 98:

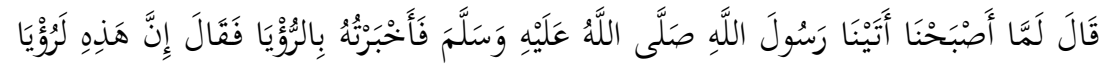

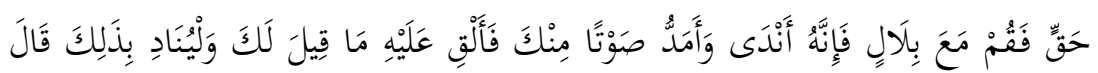

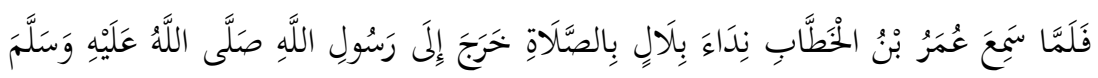

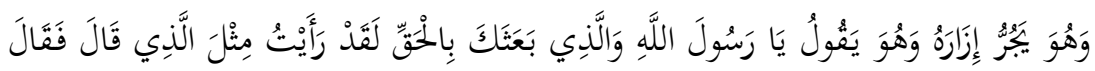

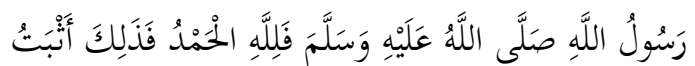

Berkatalah (Abdullah Ibn Zaid) ketika kami berpagi hari kita mendatangi Rasulullah saw. dan saya mengabarinya sebuah mimpi (tentang lafal adzan), dan beliau saw. bersabda; "sesungguhnya ini adalah mimpi yang benar, maka perintahkan Bilal (untuk melafalkannya) sebab ia mempunyai suara merdu dan panjang dari pada kalian, beritahu dia lafallafal yang disampaikan padamu (dalam mimpi). Abdullah Ibn Zaid berkata; "ketika Umar mendengar panggilan adzan shalatnya Bilal, ia pergi ke hadapan Rasulullah saw. dengan (bergegas sambil) menarik (mengangkat) sarungnya kemudian Umar berkata; "demi dzat yang mengutus engkau dengan kebenaran, saya telah bermimpi seperti (yang dikumandangkan Bilal) ini". Maka Rasulullah saw. bersabda; " maka segala puji bagi Allah, karena itu saya tetapkan itu (sebagai adzan ajakan shalat". 
banyak $^{28}$. 4) Seandainya memang adzan dan iqamah merupakan sebuah amanat yang harus dilakukan oleh Nabi saw. maka ia cukup juga diamanatkan kepada sahabat untuk melaksanakannya ${ }^{29}$. Demekian adalah beberapa alasan kenapa beliau sampai meninggalkan untuk tidak melakukan adzan sepanjang hidup beliau.

4. Nabi saw. tidak merenovasi ka'bah, padahal beliau menginginkannya:

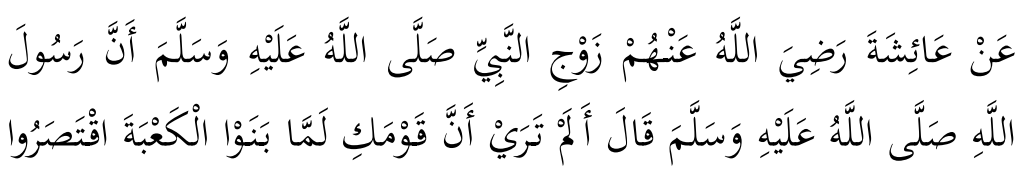

${ }^{28}$ Perkara adzan ini adalah sesuatu yang sifatnya tetap dan terus menerus. Seseorang yang telah disibukkan dengan banyaknya kewajiban terkait perkara umat tentu akan repot jika harus juga adzan. Seorang khalifah saja dapat merasakan bagaimana sibuknya mengurus umat terlebih seorang Nabi saw. hal ini dapat kita pahami dari perkataan Umar ra.:

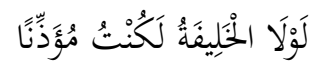

"jika bukan karena jadi khalifah saya tentu akan jadi muadzin"

Lihat Shihāb al-Dỉn Ahmad Ibn Idrīs al-Qurāfi, al-Dhakhírah Kitāb alȘalah Vol. 2 (Bairut: Dār al-Gharb al-Islāmī, 1994), h. 64. Lihat juga Yahyyā Ibn Sharf al-Nawāwi, al-Majmu' Sharh al-Muhadhdhab Kitab al-Salah Vol. 3 (Kairo: al-Mațba'ah al-Munỉriyah, tt.), h. 87, ucapan Umar ra. sebagai berikut:

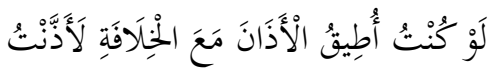

"Andai saya mampu adzan bersamaan dengan menjabat jadi khalifah, tentu saya akan adzan" 1, 403:

${ }^{29}$ Muhammad Ibn “Isā Ibn Sūrah al-Tirmidhỉ, Sunan al-Tirmidhi Vol.

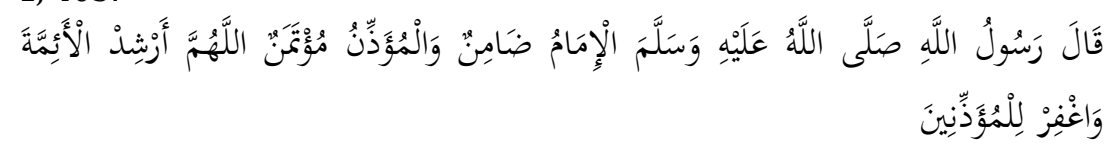

Rasulullah saw. bersabda; "seorang Imam itu adalah penjamin, sedangkan muadzin adalah orang yang dipercaya, ya Allah berilah petunjuk kepada para Imam dan ampunilah dosa para juru adzan". 


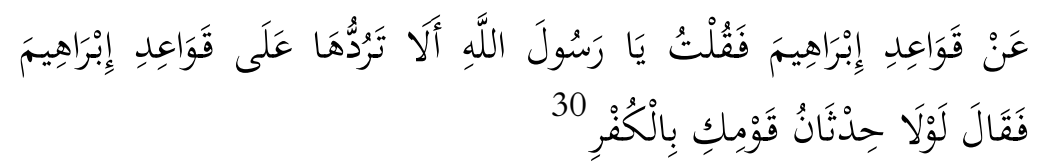

Hadis ini memahamkan kita bahwa setelah adanya musibah alam dan juga peperangan antar suku di Mekkah, yaitu selepas masanya Nabi Ibrahim as dan Ismail as. sampai dengan masa suku Quraisy zaman Nabi saw., Ka'bah telah dibangun ulang oleh orang-orang Jahiliyah tidak sesuai dengan bangunan pondasi aslinya. Nabi saw. berkeinginan merobohkan Ka'bah untuk direnovasi agar sesuai dengan pondasi-pondasi bangunan Ka'bah yang telah dibangun oleh Nabi Ibrahim as dulu. Namun karena pertimbangan beliau akan keimanan kaum Quraisy yang baru saja memeluk Islam, maka dikwatirkan jika Ka'bah direnovasi oleh beliau akan berakibat berubahnya iman kaum Quraisy.

Hadis ini juga memahamkan kita bagaimana sesuatu yang harusnya dilakukan secara syariat dapat tidak dilakukan jika hal tersebut dilakukan justru akan merubah dan mempengaruhi keimanan muslim. Dalam hal ini hifz al-din yang sifatnya darürī yaitu keimanan lebih dikedepankan dari pada hifz al-din yang sifatnya hajati -atau mungkin bahkan masuk tahsini- yaitu merenovasi Ka'bah agar sesuai dengan bangunan Nabi Ibrahim as. Hal semacam ini juga dapat menunjukkan bahwa iltizäm al-tark awla min al-fi'l (bersikap untuk tidak melakukan atau meninggalkan lebih utama dari pada dilaksanakan) ${ }^{31}$ dengan mengamalkan qaidah; $m \bar{a}^{-}$

${ }^{30}$ Muhammad Ismāril al-Bukhārī, Șahịh al-Bukhārī Vol. 3, h. 1233.

Dari sayyidah Aisyah ra. istri Rasulullah saw. sesungguhnya beliau bersabda; "tidakkah kamu lihat bahwa kaummu ketika membangun Ka'bah menyempitkannya dari pondasi-pondasi Ibrahim". Maka saya (Aisyah) berkata; "tidakkah engkau (ingin) mengembalikannya sesuai pondasi bangunan Ibrahim?". Beliau menjawab; "seandainya kaummu tidak barusan saja mentas dari kekafiran".

${ }^{31}$ Aḥmad Kāfi, Dalil al-Tark,h. 61-62. 
la haraj fihi bi al-juz' manhiy 'anhu bi al-kull (sesuatu yang sebagian sesuatu itu ada larangan (bahaya) maka terlaranglah sesuatu tersebut secara keseluruhan).

Kedua, dalam perkara sosial atau adat di mana Nabi saw. juga meninggalkan suatu amalan semisal:

1. Nabi saw. menyampaikan khutbah Jum'ah tanpa mimbar

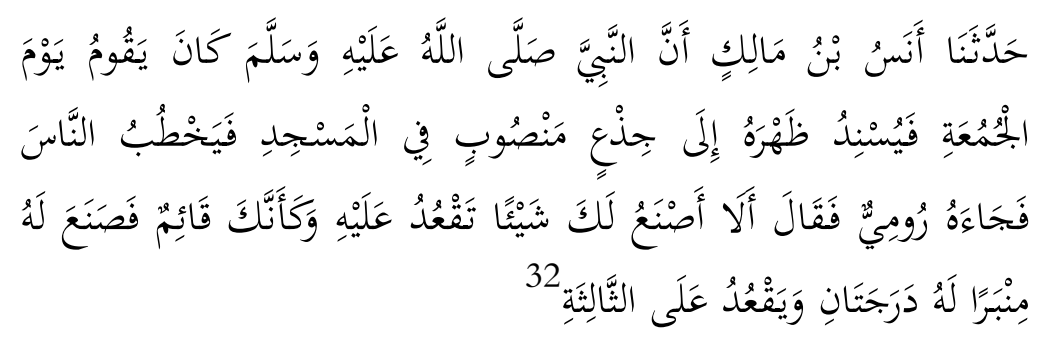

Hadis serupa juga menceritakan:

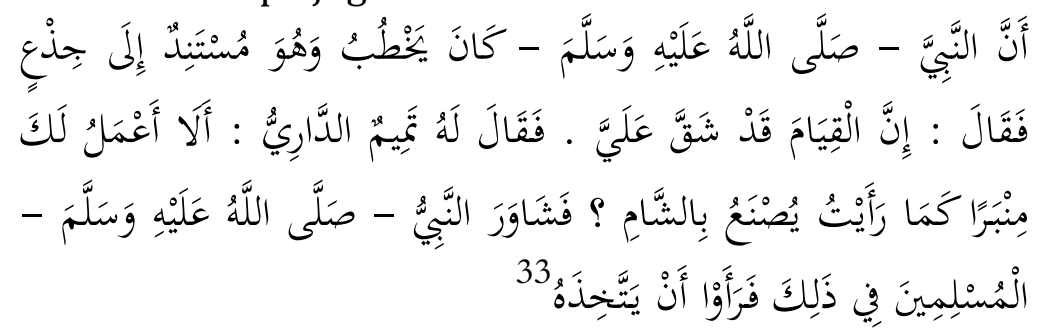

32 'Abd Allāh Ibn 'Abd al-Raḥmān al-Darāmī, Sunan al-Dārimí Vol. 1(Kairo: Dār al-Kitāb al-'Arabỉ, 1987), h. 33.

Anas Ibn Malik menceritakan sesungguhnya Nabi saw. (biasa) berdiri di hari Jum'at dan menyandarkan punggung beliau pada sepotong batang pohon yang ada di Masjid untuk menyampaikan khutbahnya di hadapan orang-orang, lalu ada seorang romawi dan berkata; "tidakkah (boleh) kami buatkan untuk engkau sesuatu untuk engkau duduk di atasnya namun seakan-akan berdiri (sebab tingginya tempat duduk tersebut)?", maka dibuatkanlah untuk beliau mimbar dengan dua tingkatan dan beliau dapat duduk di anak tangga yang ketiga.

${ }^{33}$ Aḥmad Ibn 'Ali Ibn Ḥajar al-Asqalānỉ, Fath al-Bärīin. 464.

Sesungguhnya Nabi saw. (terbiasa) berkhutbah dengan bersandar pada batang pohon dan beliau berkata; "sesungguhnya berdiri telah membuatku sulit (lelah)". maka berkatalah Tamim al-Dari pada beliau; "tidakkah (boleh) saya buatkan untuk engkau sebuah mimbar seperti yang saya lihat di negeri Syam", maka Nabi saw. bermusyawarah dengan 
Kedua hadis ini menunjukkan pada kita bahwa sikap Nabi saw. untuk tidak menggunakan mimbar sebab beliau secara budaya sosial hal tersebut tidak populer atau tidak ada di sekitarnya. Dalam benak Nabi saw tidak terpikir untuk berkhutbah di atas mimbar. Melihat manfaat yang ditimbulkan dari pemanfaat mimbar dalam khutbah, selanjutnya beliau memutuskan untuk selalu berkhutbah di atas mimbar. Dan demikian diikuti oleh para pengganti beliau, juga para ulama-ulama kita sampai saat ini.

2. Beliau bersikap untuk tidak memakan al-dabb (kadal atau biawak Arab) ketika ada sajian hidangan masakan kadal berada di rumah istri beliau sayyidah Maimunah (bibi dari sahabat Ibn Abbas dan juga Khalid Ibn Walid dari jalur ibu mereka berdua).

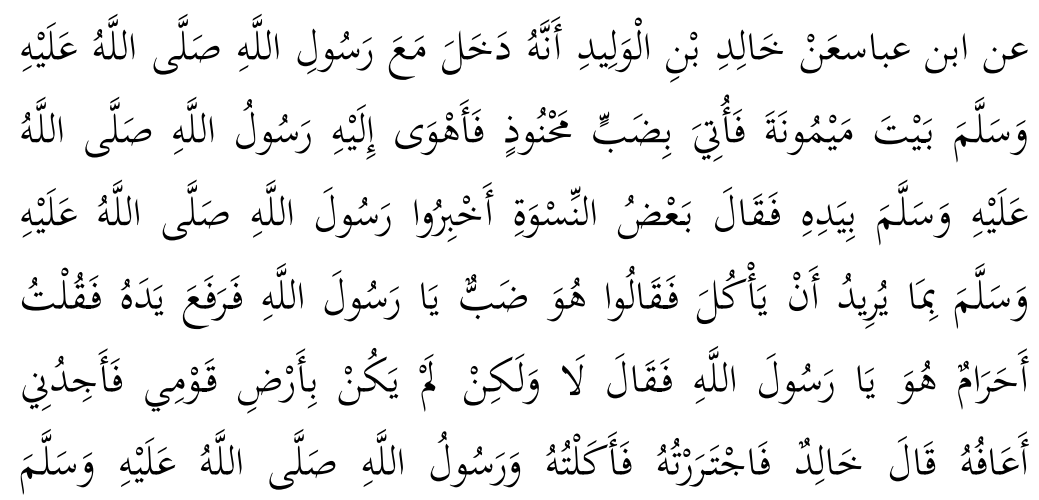

orang-orang akan tawaran itu dan mereka menyarankan Nabi saw. untuk mengambil tawaran itu.

${ }^{34}$ Muḥammad Ismā̄il al-Bukhārī, Șaḥị al-Bukhārĩ Vol. 5,h. 2106.

Dari Ibn Abbas ra., dari Khalid Ibn Walid ra. bahwasahnya dia masuk bersama Rasulullah saw. ke rumah sayyidah Maimunah ra., lalu beliau ditawari daging dabb panggang dan beliau menjulurkan tangan (untuk mengambilnya). Kemudian berkatalah sebagian wanita (yang ada di rumah); "beritahu Rasulullah saw. apa yang beliau ingin akan makan?" Mereka lantas berkata, 'Wahai Rasulullah saw., itu daging dabb." Seketika 
Juga hadis berikut:

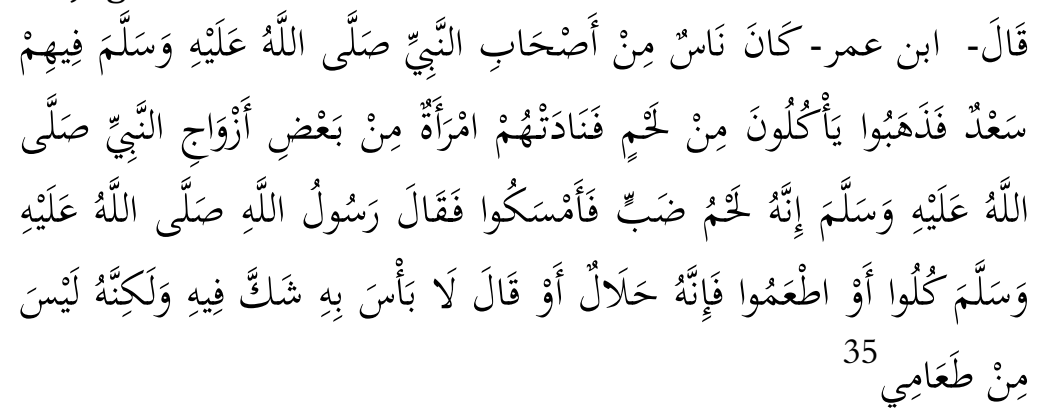

Kedua hadis ini menunjukkan bahwa beliau meninggalkan untuk tidak makan dabb bukan karena haram dagingnya, namun beliau secara pribadi merasa aneh dan tidak terbiasa saja dengan hewan tersebut sehingga beliau memutuskan untuk tidak memakannya.

Suatu amalan yang ditinggal, tidak dilakukan atau disaksikan oleh Nabi saw. juga dapat dibedakan menjadi dua dilihat dari perlu tidaknya atau menuntut untuk diamalkan atau tidaknya amal tersebut dilakukan ${ }^{36}$ :

1. Amal perbuatan yang tidak perlu dilakukan oleh Nabi saw. saat beliau masih ada (hidup). Namun hal tersebut diperlukan setelah beliau tiada (wafat). Seperti kodifikasi al-Qur'an sebab kwatir akan banyaknya para penghapalnya yang sahid di saat memerangi orang-

beliau menarik kembali tangannya. Maka aku bertanya; "Wahai Rasulullah saw. apakah (binatang) ini haram?". Beliau menjawab; "Tidak, akan tetapi binatang ini tidak ada di tanah kaumku sehingga aku merasa jijik padanya". Khalid berkata; "Aku pun mencuilnya dan memakannya sementara Rasulullah saw. melihatku.".

${ }^{35}$ Ibid.Vol. 6, h. 2652.

Ibn Umar ra. berkata: "orang-orang dari kalangan sahabat-sahabat Nabi saw. di situ ada Sa'ad, mereka memakan daging, lalu salah satu isteri Nabi saw. memanggil mereka dengan berkata, 'Itu daging dab'. Maka merekapun berhenti makan. Kemudian Nabi saw. berkata: "Makan dan nikmatilah, karena daging itu halal" atau beliau berkata: "tidak mengapa" beliau berhenti sejenak kemudian beliau berkata: "akan tetapi (daging hewan) itu bukanlah makananku".

${ }^{36} \mathrm{Abu}$ al-Faḍl 'Abd Allāh, Husn al-Tafahhum, h. 23. 
orang murtad ${ }^{37}$. Kodifikasi hadis untuk menjaga dan mengetahui kevalidan dan keabsahan segala arahan Nabi saw. agar umat yang jauh masanya dengan beliau tidak tersesatkan dengan kebohongan hadis-hadis palsu yang beredar sebab kepentingan politik penguasa saat itu atau agenda musuh Islam untuk menghancurkan dan menyesatkan kaum muslim dengan memunculkan hadis-hadis palsu. Urgensitas masalah semacam kodifikasi al-Qur'an dan hadis semacam ini pada dasarnya perlu dan boleh. Oleh sebab itu al-tark lā yuntij hukman (sikap meninggalkannya Nabi saw. pada suatu amal belum menimbulkan suatu hukum -jika tidak didukung dengan sumber hukum lainnya).

2. Amal perbuatan di masa Nabi saw. yang menuntut agar hal tersebut dilakukan, namun tidak dilakukan oleh beliau. Seperti yang dicontohkan Ibn Taymiyah tentang adzan dan iqamah untuk shalat ied (hari raya). Ia menuturkan bahwa perbuatan ini (adzan dan iqamah shalat ied) jika diyakini perlu dilakukan sebab tujuan dari perbuatan ini adalah mengingatkan dan mengajak orang-orang untuk beribadah shalat ied yang mana hal tersebut merupakan kebaikan dan dapat dikomparasikan dengan adzan dan iqamah shalat jum'at. Namun kenyataannya Nabi saw. tidak melakukan dan tidak meminta sahabat untuk mengadakan adzan dan iqamah shalat ied. Maka, hal ini menurut Ibn Taymiyah mengundang pendapat untuk melabeli adzan dan iqamah shalat ied sebagai perbuatan bid'ah besar. Dengan alasan ini pula menunjukkan bahwa sikap meninggalkannya Nabi saw. pada suatu amalan yang diyakini perlu untuk dilakukan dan tidak ada halangan juga dalam meninggalkan amalan tersebut menunjukkan itu merupakan sunnah beliau seperti halnya kesunnahan

37 'Abd Allāh Farrāj al-Sharīf, al-Tark Lā Yuntij Hukman (Ttp.: Dār alMușțafā, 2005), h. 36. 
ketika beliau melakukan suatu amalan ${ }^{38}$. Ibn Taymiyah berkata demikian sebab memegang prinsip 'adam jawaz al-sukūt fi maqām al-bayān (ketidakbolehan -Nabi saw.untuk diam di saat dibutuhkan untuk menjelaskan) ${ }^{39}$. Makanya ia berpendapat bahwa sikap meninggalkannya Nabi saw. pada suatu amal merupakan sunnah khusus yang harus lebih didahulukan dari pada dalil-dalil umum dan juga bahkan qiyas. ${ }^{40}$

Pendapat seperti yang diungkapkan oleh Ibn Taymiyah ini kami pandang kurang tepat, sebab masalah adzan dan iqamah shalat ied dapat dipahami dengan menggabungkan dan menalar masalah adzan dan iqamah untuk shalat-shalat fardhu dengan apa yang telah dipaparkan oleh hadis-hadis dalam masalah mengamalkan shalat ied ${ }^{41}$, yang dalam hal ini berlakulah al-ḥașr (penetapan hukum pada yang sudah diungkapkan dan menafikan hukum untuk yang tidak terungkap). Jadi, prinsip 'adam jawäz al-sukūt fi maqām al-bayān yufid al-ḥașr (ketiadabolehan -Nabi saw- untuk diam di saat dibutuhkan untuk menjelaskan suatu hukum dapat dipahami bahwa penetapan hukum pada yang sudah diungkapkan sebelumnya menafikan hukum untuk yang tidak terungkap). Maka, ketiadaan adzan dan iqamah dalam shalat ied bukan menggunakan al-tark sebagai dalilnya, tapi hadis-hadis tentang shalat iedlah yang menjadi dalil kenapa tidak ada

${ }^{38}$ Abū al-'Abbās Ahmmad Taqiy al-Dīn Ibn Taymiyah, Iqtiḍa al-Sirat al-Muștaqím, Mukhalafah Aṣhab al-Jahịm Vol. 1, (Kairo: Maktabah alSunnah al-Muhammadiyah, tt.), h. 279.

${ }^{39}$ Aḥmad Kāfi, Dalil al-Tark,h. 10.

40 Ibn Taymiyah, Iqtida al-Siraț al-Muștaqím, h. 280.

41 Ketentuan tidak adanya pensyariatan adzan dan iqamah dalam shalat ied bukan sebab karena beliau saw. meninggalkan atau tidak menyuruh seseorang untuk melakukan adzan dan iqamah namun sebab metode mengamalkan shalat ied yang diarahkan oleh Rasulullah saw. (al-ḥadith mā yu'mal fi al-'id) itulah yang memahamkan kita tentang tidak adanya syariat adzan dan iqamah dalam shalat ied. Lihat $\mathrm{Abu}$ alFaḍl 'Abd Allāh Ibn Muhammad, Husn al-Tafahhum, h. 24-25. 
adzan dan iqamah. Sehingga tidaklah cukup untuk melabeli haram pada suatu amal yang ditinggal oleh Nabi saw. atas dasar itu saja, haruslah didukung dengan dalil lainnya.

Dari paparan di atas dapat kita tarik kesimpulan bahwa Nabi saw. dalam meninggalkan suatu amal tertentu mempunyai beberapa sebab. Di antaranya adalah; pertama, sebab beliau tidak biasa dan merasa aneh akan hal itu, semisal makan dabb. Kedua, sebab beliau ingin menghormati hak yang lain, seperti beliau menghindari untuk tidak makan bawang sebab bau mulut orang semacam itu tidak digemari oleh malaikat. Ketiga, sebab kwatir akan diwajibkannya hal tersebut, seperti shalat malam saat Ramadhan. Keempat, sebab ada bahaya yang terkandung jika dilaksanakan seperti merenovasi Ka'bah saat orang-orang Quraisy baru masuk Islam. Kelima, sebab meninggalkannya untuk suatu hal yang lebih diutamakan seperti beliau tidak menghukum mati perempuan yang maracuninya. Keenam, sebab meninggakannya untuk menghindari kerusakan, seperti tidak mewajibkannya beliau pada umatnya untuk bersiwak $^{42}$. Ketujuh, sebab lupa, seperti beliau ketika shalat. Kedelapan, sebab beliau tidak sampai berpikir untuk melakukan hal itu, seperti penggunaan mimbar. Kesembilan, sebab sudah masuk dan menjadi mafhüm dalam dalil-dalil umum, semisal beliau tidak menggunakan tasbih dalam dzikirnya ${ }^{43}$. Kesepuluh, sebab hal tersebut dipandang boleh, semisal ketika Zaid Ibn Thābit ra. membaca surat al-Najm di hadapan Nabi saw. namun beliau tidak melakukan sujud tilawah seperti sebelumnya ${ }^{44}$. Kesebelas, sebab untuk memperingatkan, semisal beliau bersikap untuk tidak menshalati seorang muslim yang mati bunuh diri ${ }^{45}$.

42 Muslim Ibn al-Hajjāj, Șahịh Muslim Vol. 1, h. 221.

43 Aḥmad Kāfi, Dalil al-Tark, h. 62-63. Lihat juga:al-Shațibi, alMuwafaqüt Vol. 4, h. 423-429.

${ }^{44}$ Muhammad Ismācil al-Bukhārỉ, Saḥiḥ al-Bukhārí Vol. 1, h. 365.

45 Muslim Ibn al-Hajjāj, Sahịh Muslim Vol. 2, h. 673. Hadis ini dimaknai oleh Jumhur sebagai tindakan Nabi saw yang sifatnya 
Keduabelas, sebab beliau saw. ada udzur, semisal beliau meninggalkan shalat ashar sebab masih dalam keadaan perang ${ }^{46}$. Ketigabelas, sebab untuk membersihkan seperti yang beliau lakukan untuk tidak meminum perasan anggur yang sudah mengendap beberapa hari ${ }^{47}$. Keempatbelas, sebab hilangnya sebab untuk melakukannya, semisal beliau saw. yang meninggalkan berqunut setelah sebulan melakukannya ${ }^{48}$. Kelimabelas, sebab beliau sedang berijtihad seperti ketika beliau ditanya terkait boleh tidaknya seorang ibu yang masih menyusuhi berhubungan badan dengan sang suami ${ }^{49}$.

\section{Ketentuan Hukum Akibat Meninggalkannya Nabi Saw. Pada Suatu Amalan}

Pada dasarnya segala hal yang ditinggal atau tidak diperbuat oleh Nabi saw. tidaklah cukup untuk menimbulkan suatu hukum apapun baik itu wajib, sunnah, mubah, makruh ataupun haram. Sebab dalam menghukumi segala sesuatu, para ahli fikih sejak dulu dalam literatur buku ușul al-fiqh berbagai madzhab yang ada hanya mengenalkan metode-metode berikut saja yang dapat menarik suatu hukum, yaitu:

1. Wurüd al-nașs atau adanya bukti dari al-Qur'an.

2. Wurúd al-nașs atau adanya bukti dari Hadis. Al-Qura'an dan Hadis tidak diragukan kesepakatan para ulama

memperingatkan yang lainnya, bukan sebab beliau mengharamkan shalat jezanah pada seseorang yang mati bunuh diri. Lihat juga Yahya Ibn Sharf al-Nawāwỉ, Sharh al-Nawāwī 'alā Muslim Kitab al-JanảizNo. Hadis 978 (Kairo: Dār al-Khair, 1996), h. 42.

46 Muhamamad Ismāîl al-Bukhārỉ, Saḥị̣ al-Bukhārí Vol. 1,h. 216. Hadis ini dimaknai bahwa beliau tersibukkan dengan perang hingga beliau udzur tidak shalat ashar. Lihat Ahmad Ibn 'Ali Ibn Hajar alAsqalānī, Fath al-Bärīh. 83-84.

47 Muslim Ibn al-Hajjāj, Saḥị Muslim Vol. 3, h. 1590.

${ }^{48}$ Muhammad Ismāđil al-Bukhārỉ, Saḥiḥ al-Bukhārí Vol. 1, h. 341.

${ }^{49}$ Yahyya Ibn Sharf al-Nawāwī, Sharḥ al-Nawāwī'alā Muslim, h. 16. 
bahwa ia adalah sumber hukum, akan tetapi para ulama berbeda pendapat pada selain keduanya. ${ }^{50}$

3. Konsensus (ijma) atas hukum tersebut.

4. Komparasi hukum (qiyas). Mayoritas ulama menjadikan ijma dan qiyas bagian dari sumber pencarian hukum. ${ }^{51}$

5. Atau dengan metode lain (meskipun dalam metode ini masih diperdebatkan keabsahannya oleh mayoritas ulama) semacam; pendapat para sahabat, shäd aldhari'ah, amalan penduduk Madinah, mașlahah almursalah, al-istihsān, al-istișhab, dan al-hadith al-da îf.

Dengan demikian cukuplah jelas bahwa metodemetode istidlal (mencari dalil) suatu hukum di atas tidak mencantumkan al-tarkal-nabawī(sikap meninggalkannya Nabi saw pada suatu hal) sebagai salah satu metode sumber hukum, bahkan untuk masuk metode yang kategori diperdebatkan oleh ulama klasikpun tidak. Jadi, harus dikatakan bahwa eksistensi sikap Nabi saw. dalam meninggalkan sesuatu tidak akan menimbulkan hukum apapun sampai ada sumber hukum lainnya yang dapat menguatkan eksistensinya yang mengharamkan, memakruhkan atau membolehkannya. ${ }^{52}$

Allah swt. berfirman:

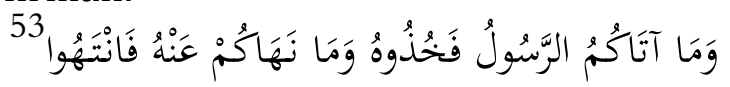

Dari ayat ini dapat dipahami bahwa Allah swt. tidak

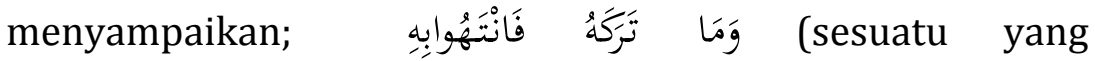
ditinggalkannya -tidak dilakukannya- maka tinggalkan). Ini dapat dipahami bahwa al-tark al-nabawí tidaklah berdampak makruh terlebih haram jika tidak didukung

${ }^{50}$ Abū al-Faḍl 'Abd Allāh Ibn Muhammad, Husn al-Tafahhum, h. 8.

51 Idem.

52 Idem, h. 11.

53 QS al-Hashr : 7

"sesuatu yang diberikan oleh Rasul kepada kalian maka terimalah, dan sesuatu yang dilarangnya bagi kalian maka tinggalkanlah" 
dengan sumber-sumber hukum di atas. Al-Shātibī memang mengutarakan bahwa asal dari hal yang ditinggalkan oleh Nabi saw. adalah makruh atau haramnya hal tersebut, namun kemudian dia menyebutkan beberapa sebab yang sudah penulis utarakan sebelumnya bahwa suatu hal yang ditinggal tersebut tidaklah mengarah pada kemakruhan atau keharaman jika sesuai sebab-sebab yang ada ${ }^{54}$. Dengan kata lain bahwa sikap meninggalkannya Nabi saw. semata tidaklah menimbulkan hukum apapun. Demikian yang kita pahami dari hadis beliau:

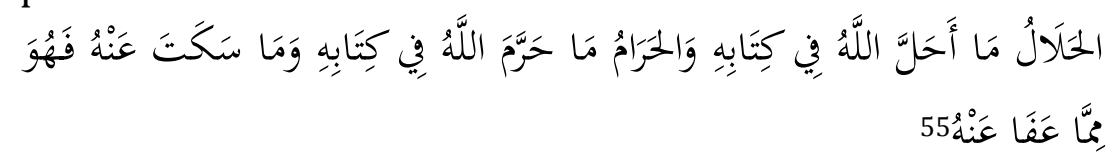

Orang-orang yang perpendapat bahwa al-tark merupakan sumber hukum berdalih dengan dalil hadis yang diriwayatkan Ibn Umar ra. tentang Nabi saw. yang menanggalkan untuk tidak memakai cincin ${ }^{56}$. Padahal, dalil keharaman memakai cincin emas bagi laki-laki tidaklah karena hadis Ibn Umar ra. semata, namun juga didukung

${ }^{54}$ Al-Shatibi, al-Muwafaqāt Vol. 4, h. 422.

55 Abū 'Ảbd Allāh, Sunan Ibn Mājah, h. 1117. Terjemahan hadis ini sudah ada di footnote sebelumnya. Hadis ini sebagai prolog dari surat Maryam ayat 64:

$$
\text { وَما كَانَ رَبْبَكُ نَسِيَّا }
$$

"dan tidaklah Tuhan engkau itu kelupaan"

56 Muhammad Ismāî̉ al-Bukhārī, Șahịh al-Bukhārī Vol. 6, h. 2662.

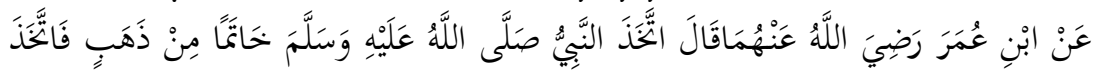

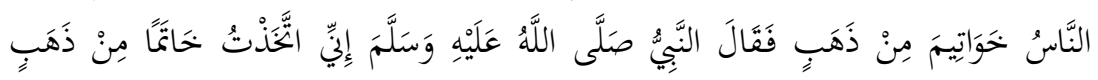

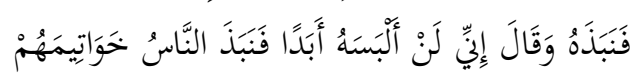

Dari Ibn Umar ra. berkata; "Rasulullah saw. (pernah) memakai sebuah cincin terbuat dari emas, maka orang-orangpun memakai cincin emas mereka". Maka Nabi saw. berkata; "sesungguhnya saya memakai cincin dari emas maka saya telah melepasnya", beliau melanjutkan; "sesungguhnya saya tidak akan memakainya selamanya". Maka orangorangpun melepas semua cincinnya". 
dengan hadis lainnya semisal hadis yang diriwayatkan oleh Abū Mūsā al-Ash'āri ra. yang menceritakan bahwa beliau saw. mengharamkan sutra dan emas untuk muslimin dan menghalalkannya untuk muslimat ${ }^{57}$. Mawlānā al-Ghumari juga menjelaskan bahwa menjadikan hadis riwayat Ibn Umar ra. sebagai dalil al-tark berindikasi haram atau makhruh tidaklah tepat, sebab al-tark diriwayat tersebut timbul setelah adanya fi'il (perbuatan). Sedangkan al-tark di sini sesuai definisi sebelumnya adalah segala amal yang ditinggalkan dan tidak pernah dilakukan Nabi saw. ${ }^{58}$

Para sahabat di zaman Nabi saw. sudah diingatkan terkait akan sikap-sikap yang tidak beliau saw. lakukan untuk tidak ditelisik jawabannya pada beliau. Seperti yang diceritakan Abu Hurairah ra.:

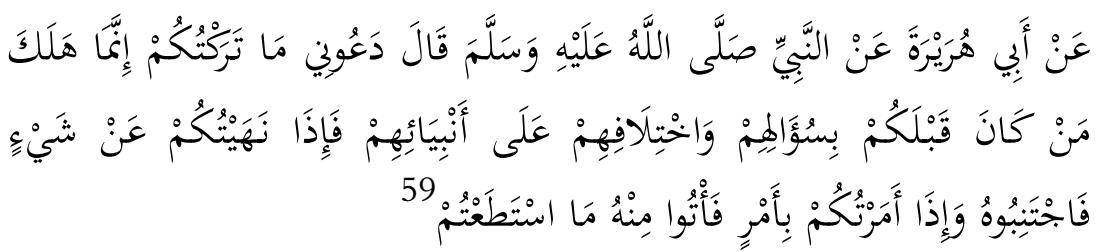

Hadis ini jelas bahwa beliau tidak berkata; تَرَكَكَهُ فَانتتَهُوابِِ. Jadi, tidaklah menjadi hal yang baik jika berpendapat

${ }^{57}$ Al-Tirmidhỉ, Sunan al-Tirmidhi Vol. 1, h. 190:

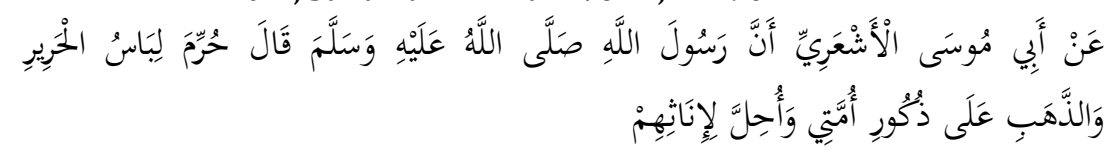

Dari Abū Mūsāal-Ash'rí ra. bahwa Rasulullah saw bersabda; "diharamkan memakai sutra dan emas bagi para lelaki dan halal bagi para perempuannya".

${ }^{58} \mathrm{Abu}$ al-Faḍl 'Abd Allāh, Husn al-Tafahhum, h. 21.

${ }^{59}$ Muhammad Ismāâil al-Bukhārī, Sahịh al-Bukhārī Vol. 5, h. 2659.

Dari Abu Hurairah ra., dari Nabi saw. bersabda: "biarkan saya atas apa yang telah saya tinggalkan pada kalian, sesungguhnya umat sebelum kalian musnah sebab banyaknya pertanyaan dan perdebatan mereka dengan nabi-nabinya. Maka jika saya melarang kalian atas sesuatu maka jauhilah dan jika saya perintahkan sesuatu maka laksanakanlah sekuatnya." 
bahwa sesuatu yang ditinggalkan Nabi saw. atau sesuatu yang tidak dilakukannya menjadikan sesuatu tersebut makruh atau bahkan haram tanpa melihat sumber yang lain. Justru segala sesuatu yang beliau tidak lakukan dan beliau tinggal sebaiknya menjadi ladang ijtihad untuk dieksploitasi dengan sumber-sumber hukum lainnya. Lihat bagaimana kita diingatkan oleh Allah swt. dalam surat al-Nahl ayat 116:

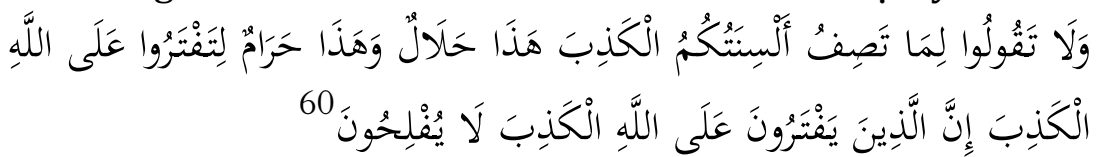

Rasulullah saw. juga mengingatkan dalam hadisnya bahwa banyaknya dosa kaum muslim juga sebab banyaknya pertanyaan tentang hal yang sebenarnya tidaklah haram namun diharamkan sebab alasan subjektifnya semata:

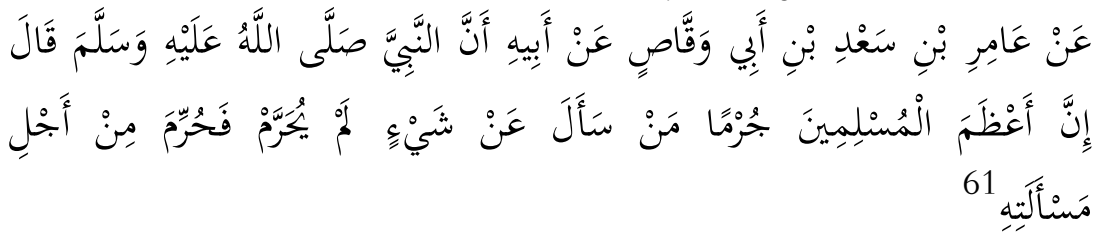

Dari apa yang sudah disampaikan menunjukkan bahwa jika al-tark tidak mengarah pada keharaman, ia sesungguhnya lebih mengarah pada kebolehan. Ini dapat dipahami dari perilaku di akhir-akhir hidup Nabi saw. yang tidak lagi berwudhu dari sebab selepas makan makanan yang dimasak atau dipanaskan ${ }^{62}$ yang mana sebelumnya

${ }^{60}$ QS. Al-Nahl : 116

Dan janganlah kamu mengatakan terhadap apa yang disebut-sebut oleh lidahmu secara dusta "ini halal dan ini haram", untuk mengada-adakan kebohongan terhadap Allah. Sesungguhnya orang-orang yang mengadaadakan kebohongan terhadap Allah tiadalah beruntung"

${ }^{61}$ Muhạmmad Ismā'il al-Bukhārī, Șaḥị̣ al-Bukhärĩ Vol. 5,h. 2659.

Dari Amir Ibn Sa'ad Ibn Abi Waqas dari Ayahnya sesungguhnya Nabi saw. bersabda: "bahwasahnya mayoritas dosa muslim adalah orang yang bertanya tentang suatu yang tidak haram namun ia mengharamkannya sebab alasan pribadinya".

62 Aḥmad Ibn Shu'ayb Ibn 'Ali al-Nasāí, Sunan al-Nasải Vol. 1, h. 109:

Al-Qānūn, Vol. 20, No. 1,Juni 2017 
beliau selalu berwudhu yang seakan-akan makan makanan yang dimasak dengan api dapat membatalkan wudlu. Seandainya selepas makan makanan yang dimasak itu mengharuskan berwudhu ${ }^{63}$, tentu beliau tidak akan meninggalkannya. Ini menimbulkan rumus usuliyah; ja’iz altark laysa bi wajib (kebolehan sebuah al-tark bukanlah sebuah kewajiban). ${ }^{64}$

Pada dasarnya orang-orang yang berpendapat bahwa al-tark sendiri adalah dalil atas keharaman atau kemakruhan jika hal tersebut dikembalikan pada diri mereka sendiri, niscaya mereka akan banyak menemukan hal-hal yang tidak dilakukan dan ditinggalkan oleh Nabi saw. telah mereka lakukan dalam aktifitasnya. Masalah budaya atau sosial terutama di saat ini, sangat banyak yang tidak dijumpai dan ditinggal untuk tidak dilakukan oleh Nabi saw., semisal makanan, pakaian, profesi, metode belajar (formal, informal, pesantren, sekolah dst.), bacaan, alat komunikasi dan transportasi. Dalam masalah ibadah misalnya adanya shalat terawih berjamaah di hampir setiap pelosok daerahnya orang muslim, shalat tahajjud berjamaah di malam Ramadhan, bacaan doa-doa para Imam tidak semua

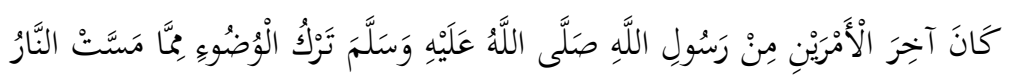

Lihat juga Sulaymān Ibn al-Ash'ath al-Sijistāni al-Azdi, Sunan Ibn Majah Kitab al-Tahärah No. Hadis 192 (t.t: Maktabah al-'Așriyah, t.th.), 50.

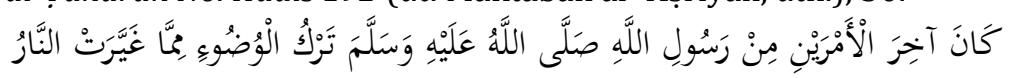

Lihat: Ibn Ḥajar al-Asqalānī, Fath al-Bärīh. 373.

Diterangkan di sini bahwa awal mula memang Nabi saw. memerintahkan untuk mengambil wudhu selepas makan makanan yang dimasak. Namun kemudian beliau terlihat oleh para sahabat terutama (riwayat Jabir ra.) tidak lagi berwudhu selepas beliau makan makanan yang dimasak atau dipanaskan.

${ }^{63} \mathrm{Al}-\mathrm{Nasā} \mathbf{i}$, Sunan al-Nasa’îlVol. 1, h. 107:

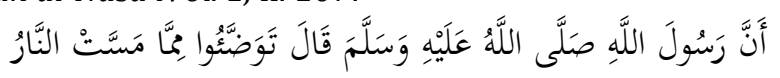

${ }^{64}$ Abū al-Faḍl ‘Abd Allāh, Ḥusn al-Tafahhum, h. 23. 
ma'thür dari Nabi saw. yang mana mereka juga kadang melakukannya.

Kehati-hatian dalam melabeli suatu hal dengan kata haram dapat kita pelajari dari seorang sahabat Nabi saw. yaitu 'Abd Allāh Ibn 'Umar ra. yang pernah melontarkan kata bohong pada seorang Tabi'in yang salah menukil redaksi kata naha (melarang) diganti dengan harama (melarang) di saat Tabi'in tersebut bercerita ulang darinya sebuah hadis tentang mencampur kismis dan kurma; نَهَى رَسُوْلُ اللَّهِ عَن الَّبَيْبَ وَ التَّمْر يَعْنى انْ يُخْطًَا oleh Tabi'in tersebut disampaikan pada teman dibelakangnya yang saat itu juga satu majelis namun kurang mendengar apa yang disampaikan oleh Ibn Umar ra.

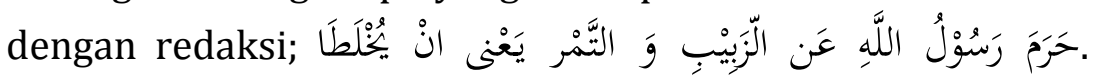
Tabi'in yang mengganti redaksi kata tersebut dikatakan oleh Ibn Umar ra. telah berbohong, yang walaupun kedua kata tersebut kita pahami hampir semakna. ${ }^{65}$

\section{Respon Nabi Saw. Terhadap Perilaku Sahabat Yang Mengada-Ada Dalam Beribadah}

Dalam berbagai kitab-kitab hadis dan juga sirah nabawi kita menjumpai beberapa sahabat beribadah dengan logika mereka, yaitu ibadah yang tidak diajarkan oleh Nabi saw. mereka para Sahabat berijtihad sendiri dengan meyakini bahwa yang mereka lakukan adalah bentuk ibadah yang tidak kontradiktif dengan apa yang sudah diajarkan oleh Nabi saw. Semisal:

65 Dalam hal ini Ibn Mubarak berpendapat hal tersebut bisa jadi hanya sebuah adab atau etika jika memakai kata nahy, sedangkan jika memakai kata haram tentu akan dimaknai sebagai hukum yang harus dipenuhi untuk tidak dilakukan. Hal ini dapat diketahui bahwa seorang sahabat di zamannya tabi'in sangat berhati-hati untuk mengatakan haram. Tentu kita harus juga lebih berhati-hati untuk mengatakan haram pada suatu hal. Lihat Abū al-Faḍl 'Abd Allāh, Husn al-Tafahhum, h. 26-27. 
1. Nabi saw. mendapati sahabat berdoa dalam i'tidal shalat dengan doa yang tidak diajarkan oleh beliau namun ketika beliau mengetahuinya beliau tidak melarangnya dan justru mengabarkan bagaimana doa tersebut sangat diapresiasi oleh para Malaikat.

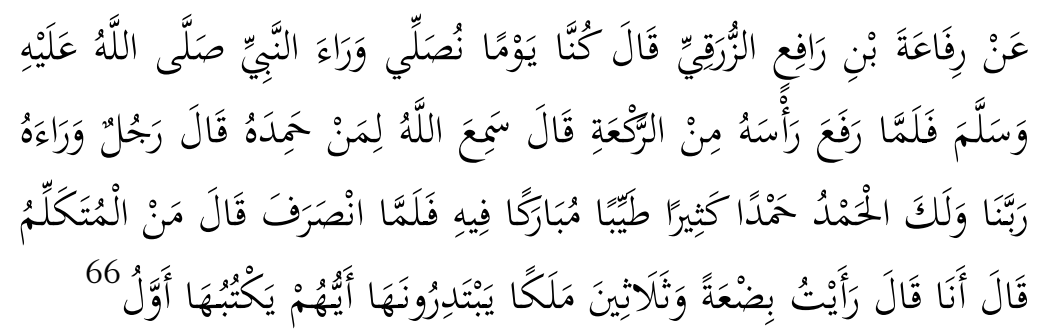

2. Nabi saw. mempertanyakan amalan ibadah Bilal ra. yang membuat beliau takjub sebab mendengar derab langkah Bilal ra. di surga. Amal ibadah Bilal ra. yang selalu shalat selepas melakukan bersuci ini selanjutnya tidak dilarang oleh beliau saw.

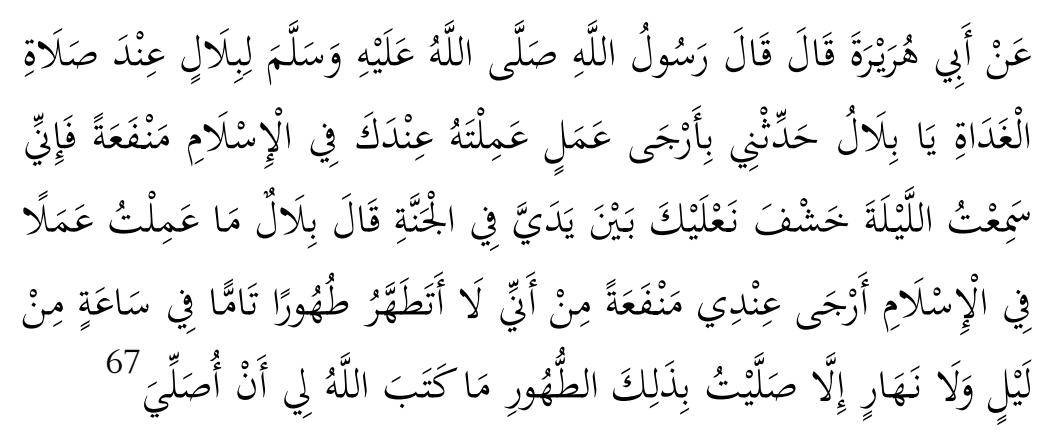

${ }^{66}$ Muhammad Ismāōil al-Bukhārī, Saḥih al-Bukhārī Vol. 1, h. 276.

Dari Rifa'ah Ibn Räfi' al-Zurāqi berkata; "suatu hari kami shalat di belakang Rasulullah saw. dan ketika beliau mengangkat kepala beliau bangun dari ruku', beliau melafalkan "sami'a Allah li man hamidahu", berkata seseorang (yang makmum) di belakang beliau; "rabbana" wa laka al-ḥamd hamdan kathïran țayyiban mubārakan fihi", maka ketika beliau telah menyelesaikan shalat beliau bertanya; "siapa tadi yang berkata?". Seseorang tersebut menjawab; "saya", beliau saw. berkata; "saya melihat tigapuluh sekian malaikat sibuk berebut untuk menulis pahala"

${ }^{67}$ Muslim Ibn al-Hajjāj, Saḥị̣ Muslim Vol. 4, h. 1910. 
3. Nabi saw. mengabarkan kabar gembira pada seorang sahabat yang gemar membaca surat al-Ikhlaș selepas baca surat al-Fatihah dan sebelum membaca surat yang lain dalam tiap shalatnya. Di mana amalan membaca alIkhlaș di antara al-Fätihah dan bacaaan ayat dalam shalat seperti itu tidak diajarkan oleh Nabi saw. terbukti banyak sahabat yang mempertanyakan keabsahan amalan itu. Dan nyatanya, amalan itu dapat memasukkan pelakunya ke surga.

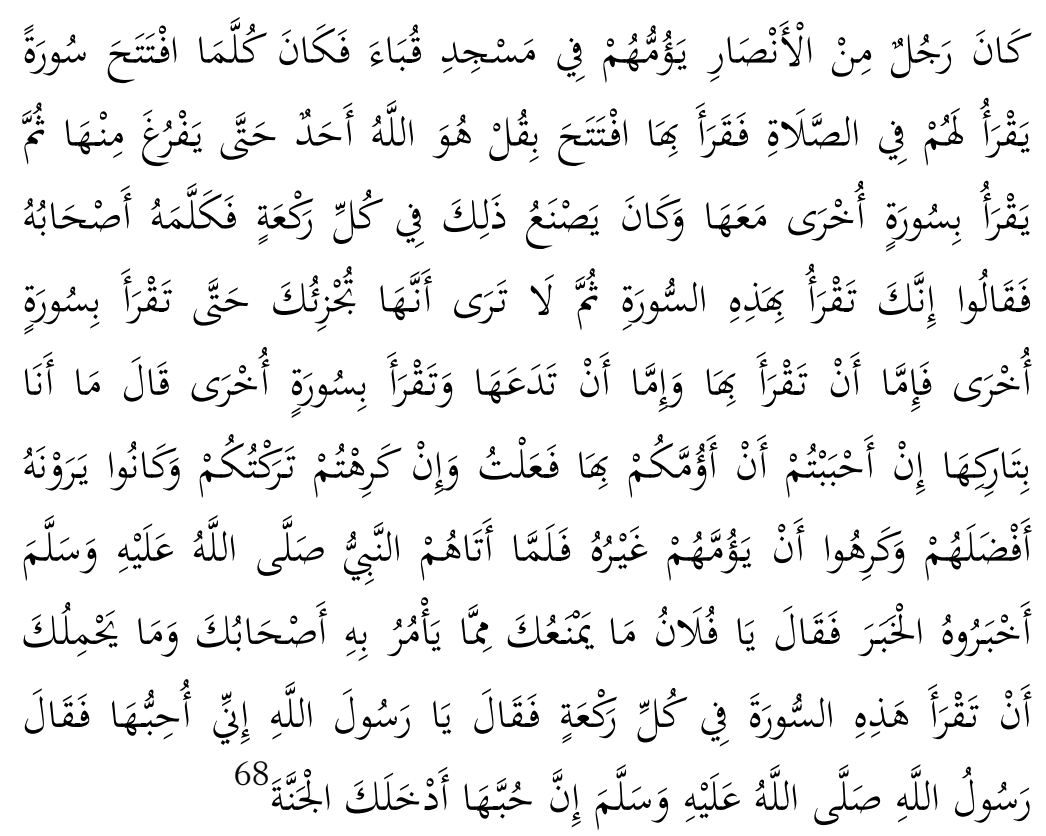

Dari Abu Hurairah ra. Rasulullah saw. berkata" Hai Bilal, katakanlah Kepadaku apa amalan terbesarmu yang pernah kamu lakukan dalam Islam, sebab aku mendengar derap sandalmu tadi malam di dalam surga?", Bilal menjawab; 'Ya Rasulullah, sungguh saya tak mengerjakan amal perbuatan yg besar pahalanya dalam Islam selain saya bersuci dengan sempurna, baik itu pada waktu malam ataupun siang hari, dan dengan bersuci tersebut saya mengerjakan shalat selain shalat yang telah diwajibkan Allah kepada saya."

${ }^{68} \mathrm{Al}$-Tirmidhi, Sunan al-Tirmidhi Vol. 5, h. 157. Lihat juga Abū 'Abd Allāh, al-Mustadrak 'alāal-Ṣaḥiḥayn Vol. 1, h. 512. 
Demikianlah Nabi saw. dalam beberapa hadis dan sírah nabawí jika kita ingin mengkaji lebih dalam akan kita dapat banyak amalan-amalan sahabat yang Nabi saw. sendiri tidak melakukannya dan tidak mengajarkan atau memperintahkannya. Baik itu dalam perkara yang ada hubungannya dengan ibadah ataupun yang sifatnya adat. Semisal perkara adat yaitu memainkan permainan tertentu untuk merayakan hari raya. Di zamannya Nabi saw. juga telah terjadi dan hal itu dibiarkan oleh beliau ketika ada orang-orang Habasyah berkulit hitam memainkan permainan tertentu dalam merayakan hari raya di Masjid 69 yang mana beliau sendiri tidak pernah memainkan sesuatu di Masjid kecuali untuk beribadah dan dakwah.

"Seseorang (sahabat) dari al Anshar mengimami (shalat) mereka (para shahabat lainnya) di Masjid Quba. Setiap ia membuka bacaan (di dalam shalatnya), ia membaca sebuah surat dari surat-surat (lainnya) yang ia (selalu) membacanya. Ia membuka bacaan surat di dalam shalatnya

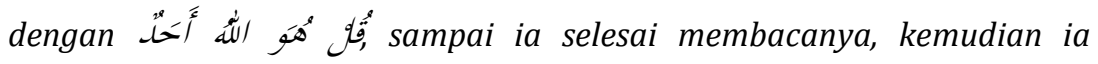
lanjutkan dengan membaca surat lainnya bersamanya. Ia pun melakukan hal demikan itu di setiap raka'at (shalat)nya. (Akhirnya) para sahabat lainnya berbicara kepadanya, mereka berkata: "Sesungguhnya engkau membuka bacaanmu dengan surat ini, kemudian engkau tidak menganggap hal itu telah cukup bagimu sampai (engkau pun) membaca surat lainnya. Maka, (jika engkau ingin membacanya) bacalah surat itu (saja), atau engkau tidak membacanya dan engkau (hanya boleh) membaca surat lainnya". Ia berkata: "Aku tidak akan meninggalkannya. Jika kalian suka untuk aku imami kalian dengannya, maka aku lakukan. Namun, jika kalian tidak suka, aku tinggalkan kalian," dan mereka telah menganggapnya orang yang paling utama di antara mereka, sehingga mereka pun tidak suka jika yang mengimami (shalat) mereka adalah orang selainnya. Sehingga tatkala Nabi Shallallahu 'alaihi wa sallam mendatangi mereka, maka mereka pun menceritakan kabar (tentang itu), lalu ia (Nabi) bersabda: "Wahai fulan, apa yang menghalangimu untuk melakukan sesuatu yang telah diperintahkan para sahabatmu? Dan apa pula yang membuatmu selalu membaca surat ini di setiap raka'at (shalat)?" Dia menjawab, "Sesungguhnya aku mencintai surat ini," lalu Rasulullah $n$ bersabda: "Cintamu kepadanya memasukkanmu ke dalam surga"

${ }^{69}$ Muslim Ibn al-Hajjāj, Șahịh Muslim Vol. 2, h. 609.

Al-Qānūn, Vol. 20, No. 1,Juni 2017 


\section{E. Penutup}

Perkara al-tark akan selalu menjadi ladang luas para pakar fikih dan cendekiawan muslim untuk menelurkan sebuah hukum suatu masalah. Perbedaan tempat, budaya dan sosial di zaman Nabi saw. dengan sekarang memunculkan banyak masalah baru yang tidak kita temukan di zaman beliau. Ini mengapa al-tark akan selalu jadi ladang yang sangat luas, hal ini jika sejak awal kita katakan bahwa al-tark itu mengarah pada hukum haram maka sempitlah sikap dan tindakan yang dapat dilakukan orang muslim saat ini sebab banyaknya masalah baru yang muncul saat ini.

Seyogyanya al-tark diposisikan sebagai ruang kosong Nabi saw. dan juga para salaf shaleh. Ruang di mana seorang yang mampu berijtihad untuk dapat menemuka suatu hukum masalah baru yang timbul. Sebab segala hal yang ditinggal oleh beliau mempunyai beberapa sebab yang menuntut hal tersebut tidak dilakukannya. Baik sebab sisi manusia beliau atau lainnya seperti yang diutarakan di atas.

Akhirnya, untuk menyikapi fenomena-fenomena yang terjadi saat ini akibat dari berbedanya cara pandang melihat al-tark. Maka, sebaiknya tidak gegabah untuk menjustifikasi hal tersebut, berilah jawaban sementara kalau memang itu perlu dan janganlah sungkan untuk bilang tidak tahu. Sebab para Imam besar madzhab sudah mencontohkan ketika beliau ditanya suatu hal, semisal Imam Abu Hanifah yang sering bilang tidak tahu ketika ditanya, padahal beliau sepandai-pandainya orang di saat itu. Begitupun Imam Malik dan Imam Syafi'i yang menjawab suatu hal dengan tidak lupa berucap bahwa pendapat saya benar tapi ada kemungkinan salah, dan pendapat yang lain salah tapi ada kemungkian benar ${ }^{70}$. Begitulah kehati-hatian berpendapat yang perlu kita

${ }^{70}$ Muhammad Nașr Mihnā, Tajdìd al-Khițab al-Dínī wa Ishkaliyah alKhiläfah bayna al-Sunnah wa al-Shi'ah (Kairo: Dār al-Thaqāfiyah li alNashr, 2007), h. 6. 
teladani dari mereka, dan dalam masalah al-tark ini penulispun bersikap demikian. Wa Allah A'lam.

\section{Daftar Rujukan}

'Ạrif al-Shaykh. "Limādha Lam Yu'adhin al-Rasūl saw. wa Law Marratan Wahidan fi Hayātihi?" dalam http://islam.ahram.org.eg/NewsQ/38065.aspx,diakses pada $24 / 2 / 2017$.

'Abd Allāh Farrāj al-Sharif. Al-Tark Lā Yuntij Hukman. Ttp., Dār al-Muștafā, 2005.

'Abd Allāh Ibn 'Abd al-Raḥmān al-Darāmī. Sunan al-Dārimī Vol. 1.Kairo, Dār al-Kitāb al-'Arabī, 1987.

Abū 'Abd Allāh Muḥammad Ibn 'Abd Allāh al-Ḥākim. AlMustadrak 'alā al-Ṣahihayn Vol. 1. Kairo, Dār alMa'rifah, 1998.

Abū 'Abd Allāh Muhammad Ibn Yazīd al-Qazwinīi. Sunan Ibn Majah (Kairo: Dār Ihyyā' al-Kutub al-'Arabiyah, tt.

Abū al-'Abbās Aḥmad Taqiy al-Dīn Ibn Taymiyah. Iqtiḍ’ alSiraț al-Muṣtaqim, Mukhalafah Așhab al-Jaḥim Vol. 1. Kairo, Maktabah al-Sunnah al-Muhammadiyah, tt.

Abū al-Faḍl 'Abd Allāh Ibn Muḥammad Ibn al-Ṣiddiq alGhumāri. Husn al-Tafahhum wa al-Dark li Mas'alah alTark,Kairo, Maktabah al-Qāhirah, 2002.

Abū al-Ḥasan Sayyid al-Dīn 'Ali Ibn Abū Ali Ibn Muhammad Ibn Sālim al-Tha'labì Al-Āmadi. Al-Iḥkam fi Ușul alAhkam Vol. 1.Tahqiqq Abd al-Razzäq 'Afifi. Bairut, Maktabah al-Islāmī, tt.

Abū Ishāq Ibrāhim Ibn Mūsā Ibn Muhammad al-Shațibì. AlMuwafaqāt Vol. 4.Kairo, Dār Ibn al-Qaym, 2003.

Ahmmad Ibn 'Ali Ibn Hajar al-Asqalānī. Fath al-Bärí Sharh Sahị al-Bukhari Kitab Faḍ ỉil al-Qur'an.Kairo, Dar alRayyān li al-Turāth, 1986.

Aḥmad Ibn Shu'ayb Ibn 'Ali al-Nasā'í. Sunan al-Nasäî. Ttp., Maktab al-Mațbu'āt al-Islāmiyah, 1994. 
Ahmmad Kāfi. Dalil al-Tark bayna al-Muhaddithīn wa alUșuitiyin. Bairut, Dār al-Kutub al-'Ilmiyah, 2008.

Ibn 'Isā Ibn Sūrah al-Tirmidhî. Sunan al-Tirmidhi Vol. 1 dan 5.Bairut, Dār al-Kutub al-"ilmiyah, tt.

Mālik Ibn Anas. Muwatța' Malik Kitảb al-Salah Vol. 1.Ttp., Dār Ihyā' al-'Ulūm al-'Arabiyah, 1994.

Muhammad Ismāíl al-Bukhārì.Sahị al-Bukhārī Vol. 1,3,5, 6. Kairo, Dār Ibn Kathïr, 1993.

Muhammad Nașr Mihnā.Tajdìd al-Khițab al-Dīnī wa Ishka7iyah al-Khilaffah bayna al-Sunnah wa alShi'ah.Kairo, Dār al-Thaqāfiyah li al-Nashr, 2007.

Muslim Ibn al-Hajjāj al-Qushayrī al-Nisābūrì.Sahị Muslim Vol. 1, 2, 3. 4. Kairo, Dār Ihyā' al-Kutub al-'Arabiyah, tt.

Quṭb Muṣtafā Sānū.Mu'jam Muștalaḥat Ușul al-Fiqh (Damaskus: Dār al-Fikr, 2000.

Shihāb al-Dīn Ahmmad Ibn Idrīs al-Qurāfi. Al-Dhakhīrah Kitāb al-Salah Vol. 2,Bairut, Dār al-Gharb al-Islāmī, 1994.

Sulaymān Ibn al-Ash'ath al-Sijistāni al-Azdi. Sunan Ibn Majah. Ttp., Maktabah al-'Așriyah, tt.

Yahya Ibn Sharf al-Nawāwī. Sharh al-Nawāwī 'alā Muslim. Kairo, Dār al-Khair, 1996.

Yahyā Ibn Sharf al-Nawāwi. Al-Majmü' Sharh al-Muhadhdhab Kitab al-Salah Vol. 3.Kairo, al-Matba'ah al-Muniriyah, tt. 